\title{
Interpreting the Image of the Human Body in Premodern India
}

\author{
Dominik Wujastyk
}

Postmodernism, now fading partly into orthodoxy, partly into irrelevance, brought two new academic metaphors into common usage, especially in the fields of cultural studies and anthropology. ${ }^{1}$ The first is the metaphor of writing, derived mainly from work by the French philosopher Jacques Derrida. Using this metaphor, we can talk of discourses, textualities, inscriptions, readings, and deciphering. All experience and explanation is modeled on the act of reading and textual reception. For example, bodies may be described as "cultural artifacts, fabricated both in the writing and reading of 'body texts.'...As soon as one 'knows' one's own or another's body, it has been written discursively;...Anatomy, epidemiology, psychology, medical sociology and other body-texts frame bodies...which exercise power over its reading" (Fox 1997: 45). The second decisive metaphor, associated in particular with Michel Foucault's work on the history of madness and the evolution of clinics, is that of the human being as a body. For Foucault, the medical encounter is

a supreme example of surveillance, whereby the doctor investigates, questions, touches the exposed flesh of the patient....In the doctor's surgery, the body is rendered an object to be prodded, tested and examined.... The body is owned by the medical system, while in mental illness the body is the apparatus by which the brain is kept restrained, often against the owner's will (Lupton 1994: 24).

This is an example of metaphorical metonymy or synecdoche, the use of part of an object to refer to the whole (Lakoff and Johnson 1980: chapter 8). It may seem provocative to claim that speaking of the person as a body is an example of metaphorical language, yet it is a point worth insisting upon. In other cultures and at other times it is not always the case that the body is the first notion that comes to mind when reference is made to a human being. One of the common teachings of many branches of philosophy in ancient India was precisely the importance of breaking the link of identification with embodiment (abhiniveśa), a view that presupposes a concept of the person as distinct from embodiment, while at the same time recognizing the widespread existence of this identification and its problematic nature.

International Journal of Hindu Studies 13, 2: 189-228

(C) The Author(s) 2009. This article is published with open access at Springerlink.com DOI 10.1007/s11407-009-9077-0 
These metaphors - of writing and of the body - are often mixed in postmodern discourse as, for example, when gender is redefined as "the social inscription of sexed bodies, not the imposition of an acculturized, sexually neutral gender" (Lupton 1994: 27, citing Grosz 1990: 72-73, emphasis in original). These styles of discourse are certainly open to abuse, and everyone will have encountered examples where postmodern language has been used to shed much new darkness on topics that were formerly reasonably well-illuminated. Nevertheless, at their best, these metaphors are valuable in encouraging us to view the world differently, to find new relationships between entities, between the person and the environment.

One of the exciting aspects of body studies in the Indian context is that we find within the Indian tradition itself, from the very earliest period, a self-conscious attitude to the body as the vehicle of consciousness and as an exteriority, we might say, carrying various inscriptions. The notions of exteriority and interiority were deeply embedded in Indian thought early on. We may recall that the Sanskrit verb for "disappear, vanish" is antardha, which etymologically carries the sense of something being placed inside; conversely "appearance" is "being outside" (āvirbhū). One of the commonest words for "body" in Sanskrit, deha, is derivable from the grammatical root dih meaning "anoint, smear," and it seems at least arguable that the metaphor conveyed by this word is of the body as an external coating or covering. However, indigenous discussion of this metaphor, if it ever existed, is lost to us. Some of our earliest Indian sources, dating from the early first millennium BCE, already posit the existence of several bodies, some spiritually constructed, some physically, some psychologically. Thus, the Taittirìya Upanisad, which is largely a meditation on food and the body, posits five bodies, or "ātmans": annamaya, or the physical body derived from food; prānamaya, or the body of the vital breath or airs; manomaya, or the self of the mind; vijñannamaya, or the self as a locus of knowledge; and ānandamaya, or the self made of joy (Keith 1925: 518; Olivelle 1998: 298-311). In later Yogic and Tantric traditions, from the late first millennium CE, a whole "alternative" anatomy evolved, which mapped the body as the locus of spiritual energies and points of graduated spiritual awakening (Briggs 1982: chapter 15; Vasudeva 2004).

The variety of ancient Indian body concepts is naturally reflected in the rich Sanskrit vocabulary of names for the body, a litany of which includes such terms as śarīram, kāyah, dehah, vigrahah, àngam, vapus, kalevaram, tanus, gātram, śavah, and kunapah, each carrying its own particular connotations according to usage and etymology.

India, then, produced a rich and diverse world of body discourse all of her own. It is the visual representation of that world of discourse that this paper will survey. While several topics in this rich field of research can only be alluded to, the bibliography provides references to stimulate further studies.

This paper sets out two main arguments. In part one, a description of the adherents of the various intellectual disciplines and religious faiths in premodern India is given, each having developed distinct and different imagined bodies; for example, 
the body described in Tantric circles had little or nothing in common with the body described in medical circles. In part two, an account is given of the encounter between Āyurvedic anatomy and early colonial European anatomy which led initially to attempts at synthesis; these gave way to an abandonment of the syncretist vision of the body and the acceptance of an epistemological suspension of judgment, in which radically different body conceptualizations are simultaneously held in unacknowledged cognitive dissonance.

\section{The Many Bodies of Premodern India}

In the following sections of the paper I present a short but indicative survey of the major traditions of body representation. These brief descriptions are intended only to establish and exemplify the discrete discourses on the body in premodern India. In another context, each body discourse would merit deeper study in and of itself.

\section{The Body of Sacrifice}

The first bodies we are offered in ancient India appear not in images of the body, but in word portraits (see Figure 1). In fact, as we shall see, the visual representation of

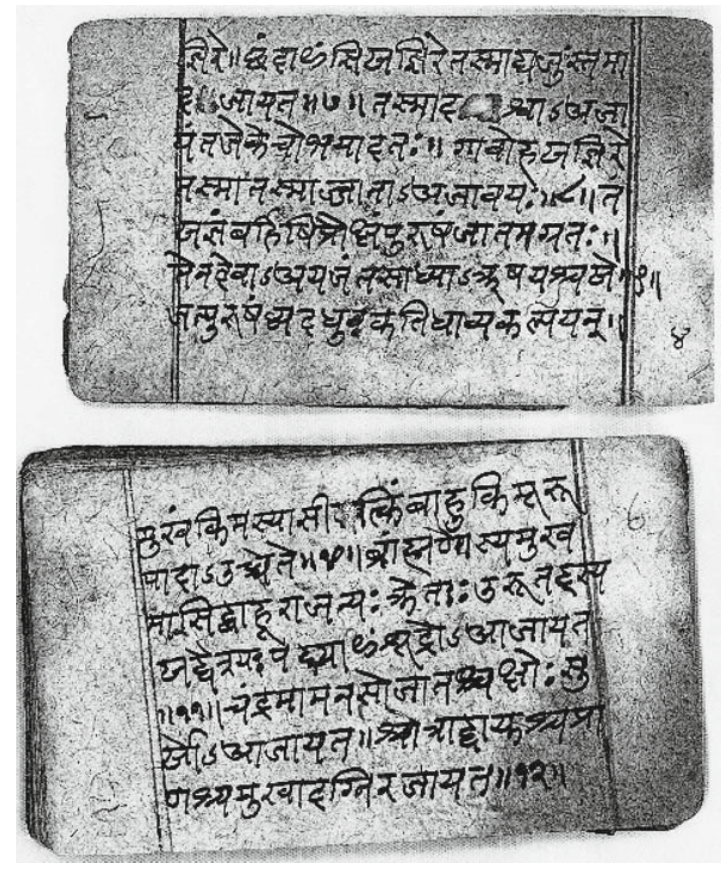

Figure 1. The body in text alone: Sanskrit manuscript folio of the Purușasukta from the Rg Veda (10.90), showing verse 11, yat puruṣam vyadádhuh..., on the sacrificial division. Wellcome MS Indic $\delta 1951$. Wellcome Library, London. 


\section{2 / Dominik Wujastyk}

the medical body is a remarkably late phenomenon in Indian culture. However, some of the very earliest texts surviving from ancient India do deal with the body in detail as the subject of elaborate sacrificial rites. In the $R g$ Veda (10.90), the famous Purușasukta, or "Hymn of Man," presents man as the original sacrificial being whose body is divided as a primal creative act. Here is an extract (Basham's [1967: 240-41] translation):

When the gods made a sacrifice, with the Man as their victim,

Spring was the melted butter, Summer the fuel, and Autumn the oblation.

From that all-embracing sacrifice the clotted butter was collected.

From it he made the animals of air and wood and village.

Thence were born horses, and all beings with two rows of teeth.

Thence were born cattle, and thence goats and sheep.

When they divided the Man, into how many parts did they divide him?

What was his mouth, what were his arms, what were his thighs and his feet called?

The brāhman was his mouth, of his arms was made the warrior, his thighs became the vaiśya, of his feet the sundra was born.

The moon arose from his mind, from his eye was born the sun, from his mouth Indra and Agni, from his breath the wind was born.

From his navel came the air, from his head there came the sky, from his feet the earth, the four quarters from his ear, thus they fashioned the worlds.

With Sacrifice the gods sacrificed to Sacrifice- 
these were the first of the sacred laws.

These mighty beings reached the sky,

where are the eternal spirits, the gods.

This famous poem has been the subject of much commentary and analysis in Indological literature, and rightly so, since so many themes of central importance make their first appearance in it. For the purposes of the present survey, however, it is of most interest to note that a sacrifice is performed in which a Man is "divided." This dividing (vidadhuh, "they divided" $\leftarrow v i \sqrt{ } d h \bar{a}$ ) of a sacrificial creature is a central act of the ancient Vedic ritual (Malamoud 1996); and it is the first time in the Indian tradition in which an account is offered of the internal parts of the animal or human. The animal to be sacrificed was often a goat, but many other creatures were also used, including oxen, sheep, horses, doves, owls, and dogs (Keith 1925: 324). And there is enough historical evidence to claim that man also was, certainly in principle, and possibly in fact, sometimes the sacrificial victim. A. B. Keith (1925: 347-48) summarized previous scholarship on the issue, basing his remarks especially on the evidence of the Vaitāna Sūtra and the Sänikhyāyana Śrauta Sūtra texts. His conclusion was that the idea of human sacrifice, though present in the ancient texts, was purely theoretical. Kenneth G. Zysk (1986: 689-90) has also surveyed several key points on this issue and finds, I think reasonably, that "the enumeration of human victims, lists of anatomical parts referring specifically to the human body,... and the procedures found in more recent ritual texts" combine to form a compelling case for the view that human ritual dismemberment really took place. This view was certainly shared by such early researchers as Rajendra Lal Mitra (1876) and Edward W. Hopkins (1895: 198-200); and human sacrifice is not a rare theme in the story literature of India (for example, Tawney and Penzer 1924: 1.116, $4.64,7.95-96)$. But whether the lists of human bones and organs offered to us by these texts are based on the actual observation of ritual killings, we need to reflect on how these lists are to be understood. Can they be read as primitive anatomical observations?

Charles Malamoud (1996) has drawn attention to many important aspects of the sacrificial process. In the Brāhmanical literature on which he mainly reported, the action of dividing the victim's body is called vibhaktih. This immediately brings to mind a parallel with the later linguistic system of Pānini, in which vibhaktih is the name given to the grammatical terminations that separate one function of a word from another. It would be wrong to read too much into this, but it is interesting to consider the extent to which animals were "inflected" in the Vedic sacrifice or words "carved up" in language analysis. Malamoud (1996: 170, citing Schwab 1886) described the stages of the sacrifice. First the creature was strangled or suffocated; then the body was washed by the sacrificer's wife; a special cake was prepared and offered up; the "carver" made an incision above the umbilicus and withdrew the omentum; then he skewered the omentum and grilled it over the fire; fragments of gold were inserted into the omentum; the officiants were given their fees; the victim 


\section{4 / Dominik Wujastyk}

was divided up and unclean parts were offered to demons; the heart was grilled; the other pieces were cooked together in a pot; from each joint or portion produced by division of the body, a small piece was removed for one of the divinities to whom the sacrifice was being offered and the remainder was distributed to the participants (emphasis added). (A few more residual actions took place.) This distribution of body parts is crucial to our interpretation of this treatment of the victim's body. The participants, the entire sacrificial team, were listed in detail, and, as Malamoud noted, it is possible to cite at least one prominent text where it is clear that "what is counted is not the number of pieces, but the number of offerings that have the dismembered body of the victim as their oblatory material. These consist of three series of elevens, amounting to thirty-three in all" (1996: 171).

What this means is, of course, that the description of the sacrificial body recoverable from the Vedic and Brāhmanical literature is determined in fundamental ways not by anatomy, but by the inner structural imperatives of the sacrifice itself. What we have is not a surgical dissection, but a liturgical numerology that happens to be expressed through a description of butchery. This does not mean that we cannot take this description of the body and learn something from it about terminology and about the level of somatic understanding that was current in that age. Zysk (1986) has done this successfully. But as he (Zysk 1986: 689b) also pointed out, it would be wrong to see in these historical records a true ancient anatomy. The understanding of the body was determined by the goals in view. As Marshall Sahlins put it, in another context, "It is by means of...tradition, endowed also with the morality of the community and the emotions of the family, that experience is organized, since people do not simply discover the world, they are taught it" (1995: 12).

The Vedic sacrificers had in view a rite which would transport them to heaven: the defining dictum is: svargakāmo yajeta, "the person who wishes to go to heaven should perform sacrifice." They did not have in view the performance of complex medical actions such as surgery, bone-setting, or massage. As Malamoud (1996: 171) noted, the body was divided up "in a way that shows a homology with the living man." The discovery of thirty-six portions in the butchered body is not an anatomical discovery of internal organs, but rather it is driven by structural imperatives such as the existence of thirty-six syllables in the poetic meter of the Vedic verse or the canonical number of thirty-six celestial worlds. In fact, the ancient texts themselves articulate the point that the meaning of the act of dividing the body is determined by the purposes for which it is carried out: "Dividing the body in this way makes the victim into a celestial being, whereas those who proceed differently hack it to pieces like thieves or brigands" (Aitareya Brāhmaña 7.1, cited in Malamoud 1996: 172). The point is to draw a magical, or at least symbolic, homology between the victim, the officiants, the divinities, and even the world at large. The body that is discovered in this process is different from the body discovered by medical and anatomical curiosity, whose final goals are quite different. Teleology determines epistemology.

Body as World: The beginning of the Purusasūkta (v.5) contains a somewhat 
cryptic remark to the effect that the original Man is both a descendent and an ancestor of an even more universal figure, called Virāt. This name is used in later literature to refer to viśvarūpa, the giant person who is identified with the universe as a whole or who is a creator figure and who famously appears in the epiphany to Arjuna in chapter 11 of the Bhagavad Gìtā (Daniélou 1991: 57-59). The metaphor of the body as an analogue of the world, microcosm and macrocosm, is one of the more familiar ideas of the body from ancient India as well as one of the oldest. It is explicit in the "Hymn of Man" cited above. It is also a recurrent theme in art and in various strands of Indian philosophical and Tantric thought (Filliozat 1999: 32). The image of universe-as-giant-person, usually called Virāt "wide-shining," is often present in manuscripts and paintings (see Figure 2).

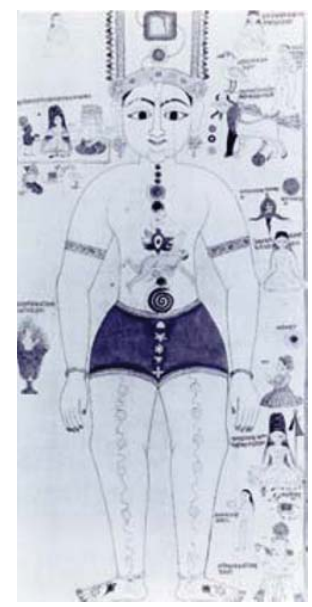

Figure 2. The body as universe: Puruṣa/Virāt/Viśvarūpa. Collection J. C. Ciancimino, London, photo Jeff Teasdale. Reproduced with permission from Ajit Mookerjee (1982: 55).

It is often asserted that the Sanskrit worldview included the idea that life in the human world was a mirror or reflection of life in a greater, divine dimension, the microcosm that mirrored the macrocosm. The famous opening passage of the Brhadaranyaka Upanișad presents a homology of the sacrificial horse and the world at large: by manipulating the horse in ritual sacrifice, one manipulates the universe (Olivelle 1998: 36-37). The Hermetic postulate "As above, so below" is indeed present in Indian tradition and is enunciated particularly clearly in medical literature from approximately the first century $\mathrm{CE} .^{2}$ The medical encyclopaedia called the Caraka Samhitā contains a dialogue in which the teacher Punarvasu asserts that, "This human being is coincident with the world: whatever kinds of entity are to be found in the world those same are to be found in the human being and whatever are to be found in the human being are to be found in the world" (5.3; Trikamji Acharya 1981: 325). ${ }^{3}$

But what is so interesting about this passage is that the assertion is not left as a vague philosophical statement: it is filled out in detail. The author has a specific set of correspondences in mind, and he is willing to explain. Thus, the world's earth is a 
human's form; water is his moisture, fire is his bodily warmth, wind is his breath, ether is his cavities, the absolute is his inner self. The passage goes on to offer personal human analogues for the Vedic gods. For example, Indra is ego, the Sun is receiving, Rudra is rage, Soma is serenity, Wind is happiness, the two Aśvins are beauty, the Maruts are enthusiasm, and so on. This narrative merits further exploration at length elsewhere: here we simply note it as a contribution to the narrative of the body as world.

\section{The Upanișadic Body}

The earlier Upanișads, dating from the first half of the first millennium BCE, present more developed reflections on the nature and function of the body (Olivelle 1998: Introduction). As was mentioned above, several kinds of body are arranged in a typology of function. But perhaps most striking is the development of many ideas concerning breath and breathing (see, for example, Bouy 1994; Zysk 1995). Five breaths are distinguished, based on location and bodily function, but also homologized in a series of ways with various parts of nature and the divine world (Filliozat 1999: 29-31). Here we see, perhaps, the influence of ideas from the ascetic milieu that was becoming increasingly important during this period. Physical states that accompany meditation exercises are noted, and the notion of levels of sleep and waking are developed. Some later Upanișads even begin to present ideas relating to the formation of the foetus (Kapani 1989).

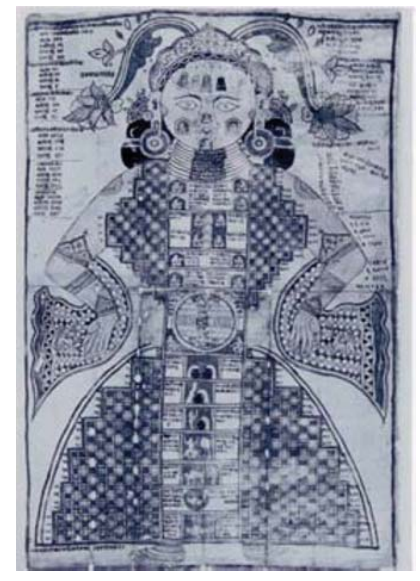

Figure 3. The Jain world as colossal human. Collection Ajit Mookerjee, photo Jeff Teasdale. Reproduced with permission from Philip S. Rawson (1973: no. 130).

\section{The Jain Body}

The Jain tradition developed a number of speculations concerning the homology of a giant man and the world at large that seem to share some features with the Virât idea. However, the Jain vision is more complex, with the vertical axis of the giant man (lokapurușa) corresponding to various levels of divine, human, and hellish habitation (see Figure 3), whose features and qualities are elaborated in the canonical literature (Caillat 1981). 
The Jain religion teaches that karma is a semi-material substance that adheres to the soul, giving it weight that holds it imprisoned in mundane existence (Dundas 1992: 83-87). Among the most striking body images in premodern India is the Jain image of the saint or ascetic who has shed all his corrupting karma and become a transcendent, pure being. Although still inhabiting the world, he is yet perfect. As such, all descriptions, all qualifications turn back from him. The use of any adjective is inappropriate and inadequate. He can be described only apophatically, by describing what he is not. And the visual analogue of this method is to portray an image of the conquering saint as an absence (see Figure 4). This powerful representation of the pure embodied soul inevitably remains in memory as a most striking and evocative vision of the human body in its most negated form.

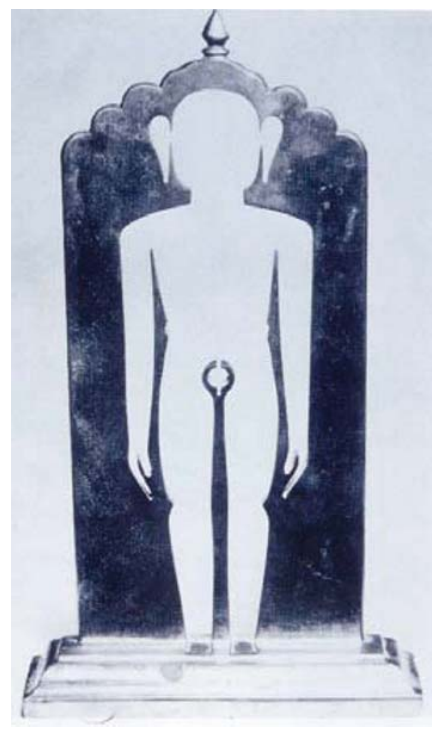

Figure 4. The apophatic body of the Jain ascetic. Collection Ajit Mookerjee, photo Jeff Teasdale. Reproduced with permission from Philip S. Rawson (1973: no. 129).

\section{The Buddhist Body}

The central formative experience which led Prince Siddhattha Gotama to renounce his royal birthright and seek a deeper meaning in life was his encounter with four bodies: bodies of people who were poor, sick, old, and dead. It is reasonably justifiable to state matters in this way, since the canonical account of this event treats only of the exteriority of these bodies, not of the personalities or nuances of the selves they embodied. During his subsequent ascetic practices, Gotama himself was treated reductively by some of the people who encountered him, especially the village boys who thought he was a "dust-goblin" (pāmśupiśāca) and spitefully drove spikes deep into his ears (see Figure 5; Wujastyk 1984b). This, like the Jain apophatic representation of the body, is a tradition that denies the importance of the body and valorizes those who are immune to physical insult. In a certain sense, the body in these traditions is irrelevant. 


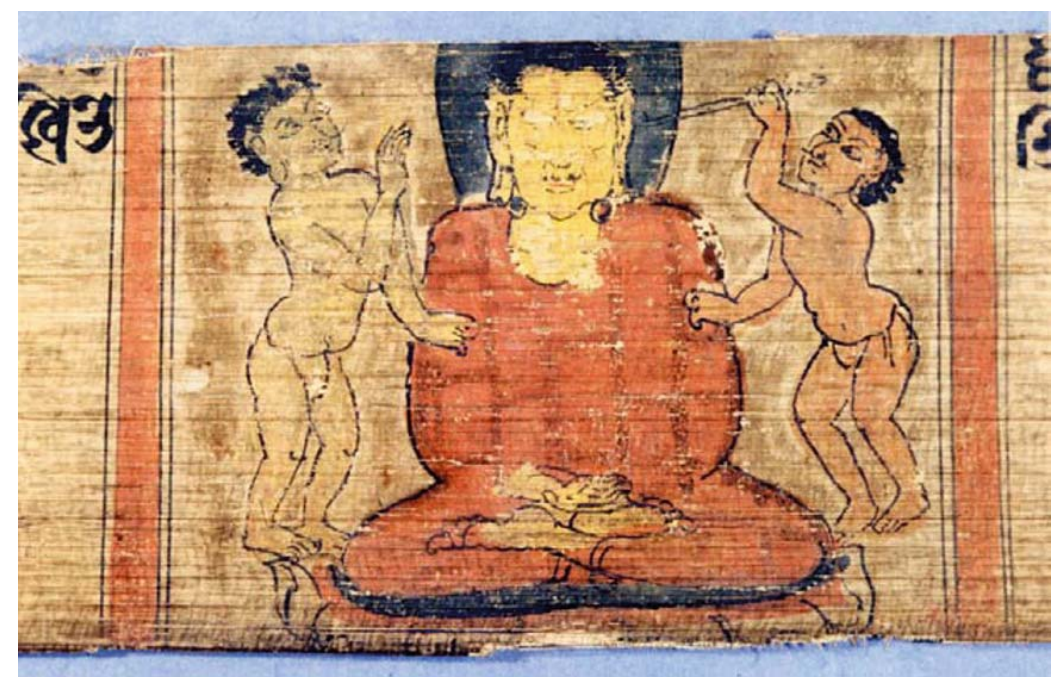

Figure 5. The Buddha is attacked by village boys. Wellcome MS Indic $\varepsilon 1$. Wellcome Library, London.

Sue Hamilton $(1995,1996)$ has provided rich materials for exploring the Buddhist idea of the body, based on a close reading of the Pali Tripitaka. In this reading, the understanding of the body is qualitatively more complex and subtle than in previous traditions. The physical body is not objectified as a physical substance, for example in contrast to mind, but rather as a combination of processes or events (Hamilton 1996: 169). The Buddhist analysis of the body discusses five skandhas, "bundles" of its experiences. The first (rüpa) is the closest to what the modern reader understands as a physical frame, made of the elements, whose essential characteristic to the Buddha was that it suffered (Hamilton 1996: 4). The next bundle is pleasurable and

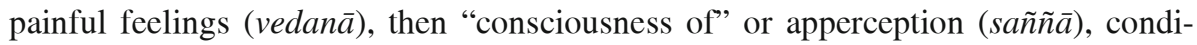
tioned volition (samkhāra), and the process of being conscious (viññanna). These may be thought of as aspects of the psychophysical continuum of the subjectively experienced "individual." This early Buddhist analysis of the body into five bundles turns out to be an analysis of clusters of experiences rather than of things. As Richard F. Gombrich noted, “The Buddha did not ask 'What is a man?' but 'How is a man' " (1996: ix; emphasis added). The Buddha was interested not in the body as an object, but in the cognitive and experiential processes that occurred concomitant to embodiment (Watson 2002: 97-101). The full understanding of this analysis constitutes a major step in Buddhist enlightenment. The bundles are all characterized by an absence of permanent essence (anattat $\bar{a})$, by unsatisfactoriness (dukkhatā), and by impermanence (aniccatā). Meditation on the body as an object lesson in transitoriness and as a memento mori became a tradition within Buddhism at an early period (for example, Dissanayake 1993: 141), as did a special focus on the female body as an object of disgust (Wilson 1995). 


\section{The Tantric Body}

During the latter part of the first millennium CE, the tradition of thought and practice described in Tantric texts began to become an important strand of Indian religious culture (Goudriaan and Gupta 1981: 20-22). Tantric religious ideas are distinguished by their self-conscious difference from Vedic ideology and by a number of other typological features (Gupta, Hoens, and Goudriaan 1979: 7-9). One of the central ideas in the Tantric view of the body is that there are six wheels, or cakras, arranged along a vertical axis in the human body and that these are implicated in the process of self-realization and the expansion of consciousness (see Figure 6). The vertical axis contains tubes called $\bar{\imath} d \bar{a}$, sușumnā, and pingala, along which prāna, or breath travels (Briggs 1982: chapter 15). This model of the body was elaborated in early Tantric and Yogic texts such as Matsyendranātha's Kaulajñānanirnya (ca. CE 900950) and Gorakșanātha's Siddhasiddhāntapaddhati (ca. CE 1000-1250), works that form the foundational literature of the Nātha tradition, but had a wide influence across all subsequent Indian religious traditions. These and other works have been called "satellite traditions of yoga" (Larson and Bhattacharya 2008: 436 et passim).

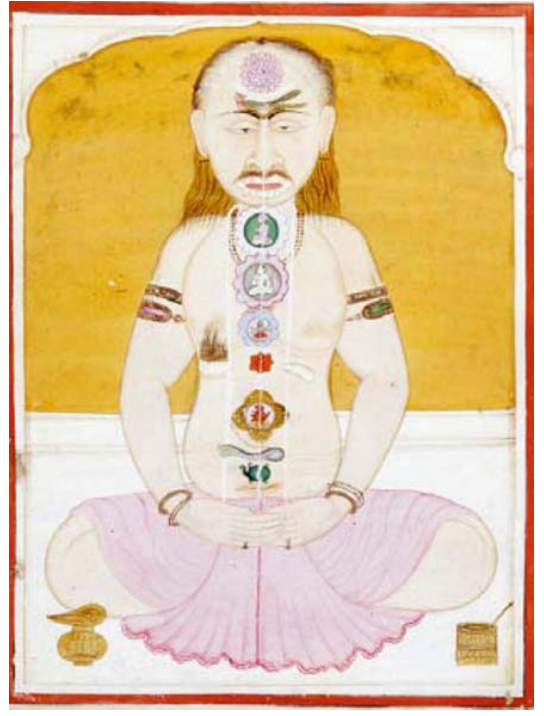

Figure 6. The body as locus of Tantrik cakras. Wellcome MS Indic $\beta 511$. Wellcome Library, London.

One such text, for example, the Dehasthadevatācakrastotra, studied by Gavin D. Flood (1993), gives the various senses and faculties and locates them in petals at the cakras within the sacred body. All of these categories and functions are subject to multiplication, variation, and homologization as generic themes in religious and mystical discourse (Padoux 1990; White 1996; Filliozat 1999). The concept of the cakras has, of course, now entered public consciousness and media worldwide, usually in an inflated version which enumerates seven, not six, cakras. The doctrine of the cakras is widely viewed as an ancient and immutable element of the Indian 
worldview. While not completely wrong, this view needs to be qualified in two directions. First, it comes as a surprise to many to discover that the idea of the cakras is a relatively recent development in Indian Tantric thought. It is datable only to the tenth century CE, making its appearance in texts such as the Kubjikämata Tantra and the Mālinivijayottara Tantra (Heilijgers-Seelen 1990). Second, the cakras make no appearance whatsoever in Āyurveda, the classical medicine of India. Notwithstanding the contemporary growth of various forms of massage and therapy focused on the cakras, there is no such theme in the classical Sanskrit literature on medicine. The cakras really are an idea specific to Tantra and Yoga, and it is not until relatively recent times that this idea has been synthesized with medical thought and practice.

To summarize, the Tantric body is yet another example of a non-anatomical body. Just as the Vedic body was profoundly implicated in ritual meaning, the Tantric body is an instantiation of the universe in miniature and a conduit for mystical energies that awaken consciousness.

\section{The Yogic Body}

The Yogic model of the body has much in common with that of the Tantric milieu. The base text of the Yoga system, Patañjali's Yoga Sütra, does not give much detail about the body, being predominantly a psychological and spiritual text. It does not even give any detail about postures (āsana), which are such a major feature of the tradition of practical Yoga. The formalization of these traditions was a gradual process, especially the development of pictorial representation. Very few manuscripts show Yogic âsanas (Sjoman 1996). The body of the yogin is to be subdued and made quiescent so that the higher states of meditation and samädhi can be realized (Figure 6). The control of breath is crucial to the experience of stillness (Eliade 1970: 55-59). Concepts of macrocosmic homology are also present in this tradition (see Figure 7).

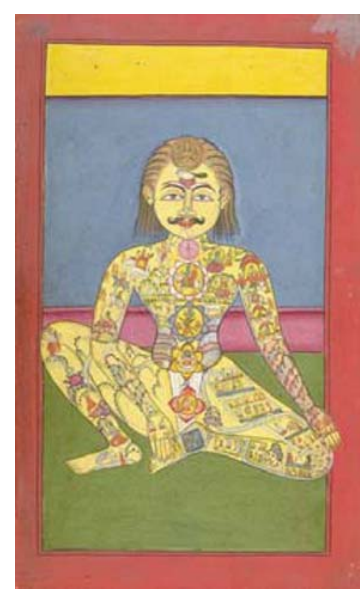

Figure 7. The yogī as macrocosm. British Library MS Add. 24099, f.118. 
The attempt to return to a literalist interpretation of Yogic and Tantric physiology and to equate it with medical/anatomical images of the body is interestingly and dramatically demonstrated in one of the works of Hamsasvarūpa Mahārāja (see Figure 8), the Șaṭcakranirūpanacitra published in about 1903. Hamsasvarūpa explicitly argues, through text and illustration, for the physical reality of the Tantric body, with its cakras, energy channels, and so forth. All these features are assimilated to features in the anatomical body of Western medicine of the late nineteenth century. Thus, Figures 9 show the Tantric and anatomical bodies side-by-side, with the anatomical body making clear, according to its caption, the locations of the cakras and $n \bar{a} d \bar{l} \mathrm{~s}$, or conduits. Figure 10 makes the same type of rapprochement between the brain and the thousand-petaled lotus-cakra in the head. Similarly, in Figure 11, the twelve-petaled anāhata-cakra is homologized with the "cardiac plexus" and a drawing in the top right corner of the image shows the anatomical treatment of heart and lungs.

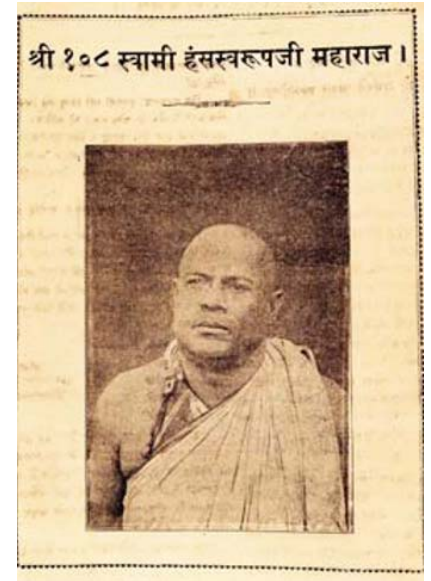

Figure 8. Hạ̣sasvarūpa

Mahārāja, author of

Saṭcakranirüpaṇacitra (1903).

Frontpiece of his edition.

It is worth noting that a belief in cakras was not uncontested even within the Hindu tradition itself. The life of the famous scholar and religious reformer Dayānanda Sarasvatî is narrated in a pseudo-autobiographical work first published at the end of the nineteenth century (Jordens 1998). A striking passage narrates Dayānanda's disillusionment in the Tantric view of the body with its cakras (Yadav 1976: 44):

At this time [1855], besides some religious works, I had with me the Shiva Sandhya, Natha-pradipika, Yoga-beejak and Kesarani-Samhita which I used to study during my travels. Some of these works gave exhaustive description of the nervous system and anatomy which I could never grasp. This made me doubt the authenticity of these books. I had been trying to remove my doubts for some time but had found no opportunity. One day I saw a corpse floating down the river. There was the opportunity to confirm the veracity of the statements contained in my books. Leaving the books nearby and taking off my clothes, I entered the river 
and brought out the dead body. I then dissected it with a large knife in the best manner I could. I took out the heart (kamala [literally "lotus"]) and cutting it from the navel to the ribs examined it. I examined a portion of the head and neck too. The description given in the books did not tally at all with the actual details. I, therefore, tore the books to pieces and threw them into the river along with the corpse. From that time, gradually, I came to the conclusion that with the exception of the Vedas, Patanjali, and Sankhya all other works on the Science and Yoga are false.

This is a fascinating passage for its iconoclasm and pragmatism. Although it is not mentioned in the narrative, it seems likely that Dayānanda would have heard of the famous dissection performed a few years earlier in 1836 in Calcutta by Madhusudana Gupta (Kumar 1998: 24-25). Gupta had already been honored for translating Robert Hooper's The Anatomist's Vade-Mecum: Containing the Anatomy and Physiology of the Human Body (1801) into Bengali, and in 1836 Gupta and his colleagues became the first Hindu Brāhmanas to perform a dissection in historical times, having studied under British medical teachers such as surgeon Peter Breton and H. H. Goodeve at the Native Medical Institution (Kumar 1998: 20). This event created such a stir that the cannons at Fort William were fired to celebrate the event. Gupta was later praised by the surgeon R. O'Shaughnessy, who saw this event as a turning point in the development of modern medical education in India (Kumar 1998: 25). It is possible that Dayānanda was, in his own manner, imitating Gupta's procedures in an attempt to apply his interpretation of the scientific method.

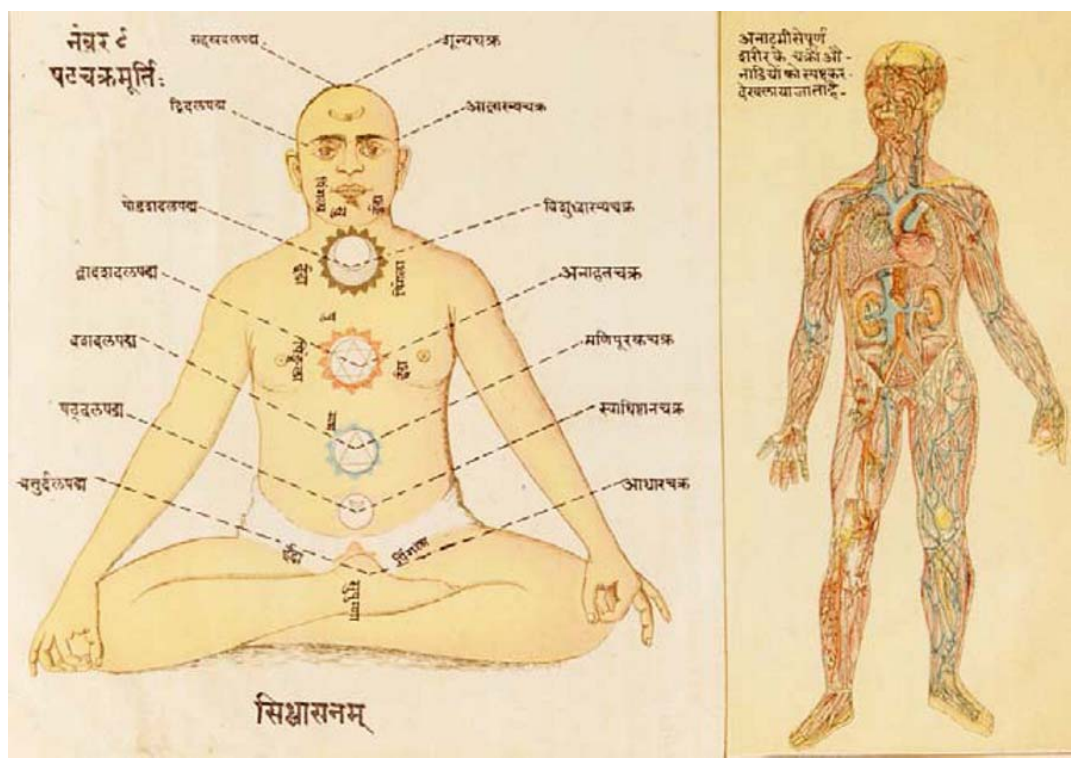

Figure 9. Șatcakranirūpaṇacitra: Tantric and anatomical bodies homologized. 
George W. Briggs (1982: 319-20) cites the work of several other authors who attempt to make the argument in the other direction, namely that the cakras and other parts of the "minute body" (sūkșmaśarìra) can be equated with organs known from anatomical analysis. Such attempts are almost always made in the absence of a sophisticated understanding of cultural relativism, of "comparative rationalities" (Sahlins 1995: 14), or even of scientific method and its presuppositions (Wujastyk 1998). Nevertheless, works such as Hamsasvarūpa's are very interesting as representing a serious attempt at an integrative approach to understanding the world. Such efforts are underpinned by the assumption that the world is one, that both traditional and modern visions of the world are true, and that all true explanations of the world can be made, somehow, to coincide. Such a belief also underlies efforts from the other side such as that of Peter Breton (1825), who attempted to unify and make equivalences in physiological vocabulary.

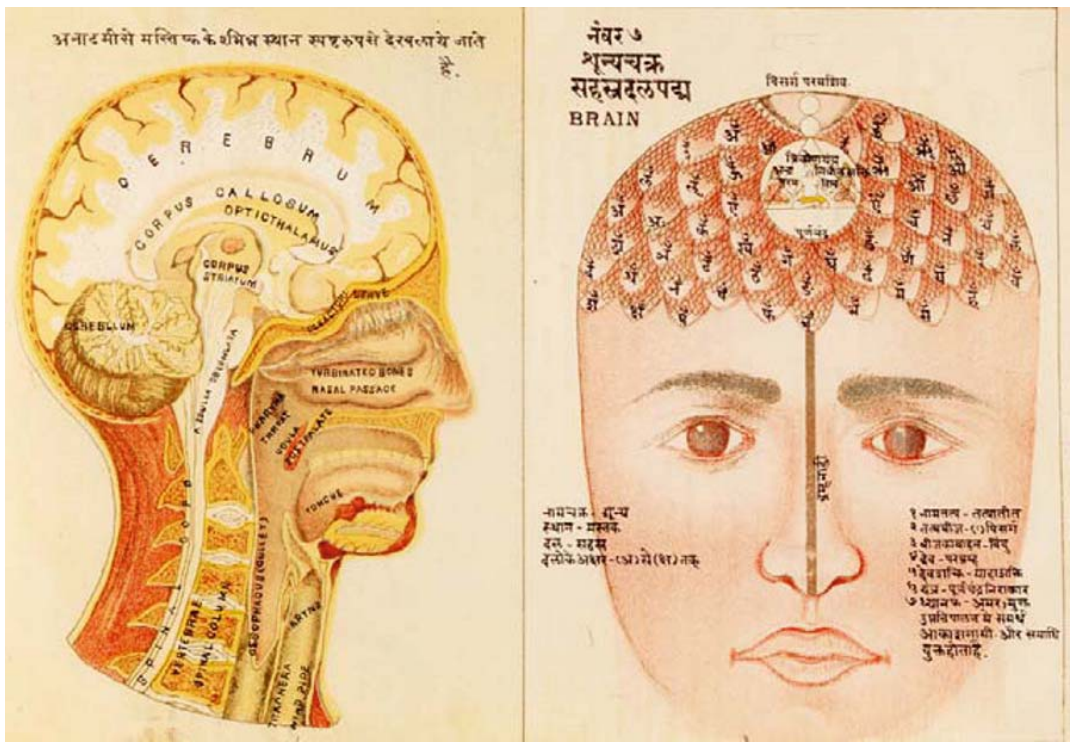

Figure 10. Șaṭcakranirūpaṇacitra: mastiṣka and brain

\section{The Wrestler's Body}

Traditions of exercise and gymnastic training are very old in India and are related both to traditions of medicine and of Yoga, as well as to martial arts and asceticism, in a fascinating and complex set of social and historical relationships (Farquhar 1925; Roşu 1981; Fedorova 1990; Deshpande 1992; Staal 1993; Alter 1997; Zarrilli 1998). Many of these traditions are still alive in Kerala, in parts of Karnataka, and elsewhere. The body of the martial arts gymnast is understood in a number of modalities, but one particularly interesting concept is the body-map of marmans. According to the medical author Vāgbhața, who wrote in about CE 600, a marman is 
a point "which pulsates irregularly and which hurts when pressed. It is a point at which the flesh, bone, sinews, pipes, ducts, and junctions all meet, where life is strongly present.... The breath of life is located in them" (Wujastyk 2003: 241).

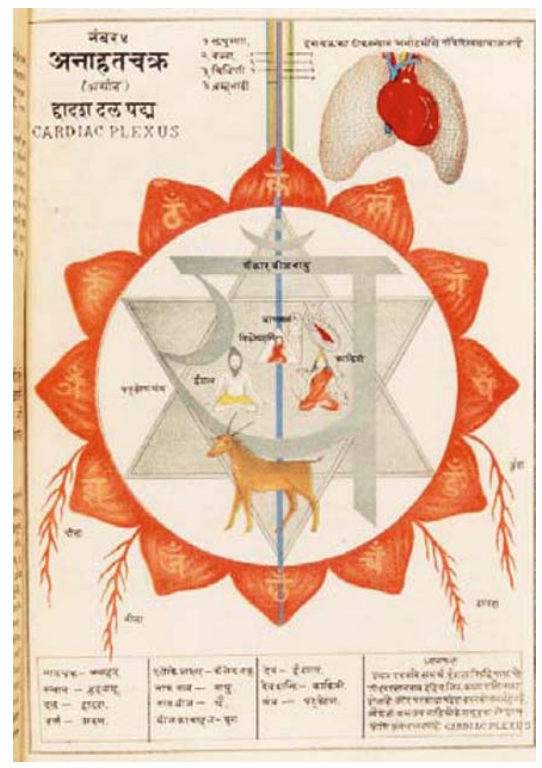

Figure 11. Șaṭcakranirūpaṇacitra: anāhata cakra and cardiac plexus.

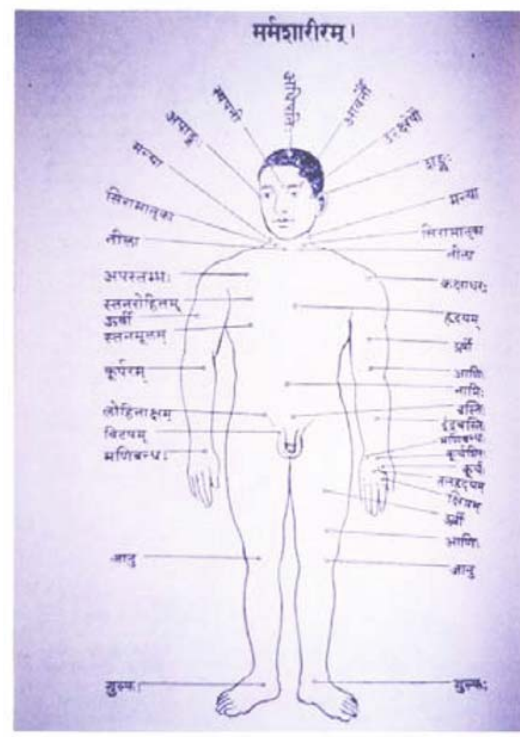

Figure 12. The marmans on the front of the body. From R.

Kiñjavaḍekara (1938-40: facing sā.53). Wellcome Or. P.B.Sansk. 702. Wellcome Library, London.

There are 107 canonical marman points (see Figure 12), and a rich and subtle branch of the martial arts literature discusses them principally as target points for attack (Zarrilli 1998: chapter 6). In medicine, too, the marmans are danger points that the surgeon must on all accounts avoid. If a patient is wounded in a marman, he is in grave danger of death. As the Suśruta Samhitā (6.16) notes, if a marman is of a "fiery" nature (ägneya), the patient may die suddenly; if it is "cooling" (saumya), he may die slowly. But die he will.

There exists a fashion in complementary health circles dating from the late twentieth century of reinterpreting marmans as points for therapeutic attention, as though they were an Indian analogue to Chinese acupuncture or moxa points. Popular literature on this subject has typically asserted that this practice can be found in lost Âyurvedic source texts (Thatte, Renu, and Verma 1988; Ros 1994). This has no historical foundation. The appeals made to lost texts or unknown parts of Āyurvedic literature have now been conclusively quashed by the completion and publication in 
2002 of G. Jan Meulenbeld's massive History of Indian Medical Literature that surveys the whole of Āyurvedic literature comprehensively. ${ }^{4}$ In Sanskrit Āyurvedic literature, on the contrary, marman points are repeatedly described as points that the physician should avoid damaging at all costs, since they are lethal (Wujastyk 2003: 242-44). They may be pressed, punched, stabbed, or kicked if the goal is to harm an opponent in martial combat (Zarrilli 1998).

\section{The Medical Body}

The bodies mentioned so far by no means exhaust the typology of bodies available for study in premodern India. The dead body, the gendered body, the erotic body, the caste body, all demand notice, to name but a few. And as mentioned at the outset, each of the categories would richly reward detailed study in its own right. The point has been to mark the boundaries between different body discourses, boundaries that were sociologically and epistemologically real: people who used these different discourses in premodern India did so in compartmentalized ways, at least as far as we can tell from the surviving historical sources. The meditating yogin (cakra) would talk in a completely different way about his body than the surgeon (cutting, probing, excision) or the martial-arts practitioner (lethal marman points). This becomes important when considering the massive conflation of categories that has taken place in the course of the modernization and globalization of Indian concepts from the twentieth century onwards. All these discrete body narratives are merged and overlaid in the bricolage of contemporary popular discourse about Indian culture.

I shall now turn specifically to the case of the medical body as it is revealed to us in the sources, since it provides good evidence for the evolution of thought about a body image from premodern times until the present.

The chief locus for knowledge of the medical body is of course the literature of classical medicine, Āyurveda. In a penetrating study of this literature from the point of view of body-knowledge, Francis Zimmermann (1983) addresses two points particularly: the epistemological position of anatomical knowledge, and the images underlying the doctrine of the humors, especially those concerning unctuosity or oiliness. One of the central claims that Zimmermann makes is that there is no "real" anatomy in the Âyurvedic literature. By "real," Zimmermann means that those parts of the body which modern medicine calls organs and views as small factories or machines for manufacturing or transforming nutrients and which may be enumerated, dissected, and so forth, are not, in Âyurveda, viewed in the same way at all. Rather, in Āyurveda "the humours are vital fluids, and the frame of the body is a network of channels through which vital fluids must be kept flowing in the right direction. The nature and function of organs like the heart, which is the centre of the network, stay indeterminate" (Zimmermann 1983: 11).

Zimmermann's argument is persuasive and has a great deal of merit. It also reminds us of several ideas from the Buddhist interpretation of the body, in which 
process is privileged over substance. However, I think that it is possible to find in Ayurvedic literature a more substance-oriented understanding of the body. The image in Figure 13 is a unique, probably eighteenth-century image of the human being. At first it may be tempting to align it with the earlier images we have seen in the course of this paper, the Virăt image (Figure 2) or the Tantric man, perhaps (Figure 6). But this would be quite wrong. A close examination of the figure shows no cakras, no universe in miniature. The image is completely medical, in the $\bar{A}$ yurvedic sense. The text labels are extracts from one of the later classic works of Ayurvedic literature (in which, we recall, the cakras and other Tantric items do not appear), the Bhāvaprakāśa of Bhāvamiśra ( $f$ l. sixteenth century; see Wujastyk 2008b). The channels and organs drawn in the torso are, in fact, enumerated very explicitly in Āyurvedic chapters on the body. And the organs are named, often áśayas, or receptacles, for one or other of the organic fluids. While we can agree with Zimmermann that the organs are not, by and large, engaged in the kind of processing which modern biomedicine expects of an "organ," they are nevertheless clearly and substantially understood repositories for biological substance.

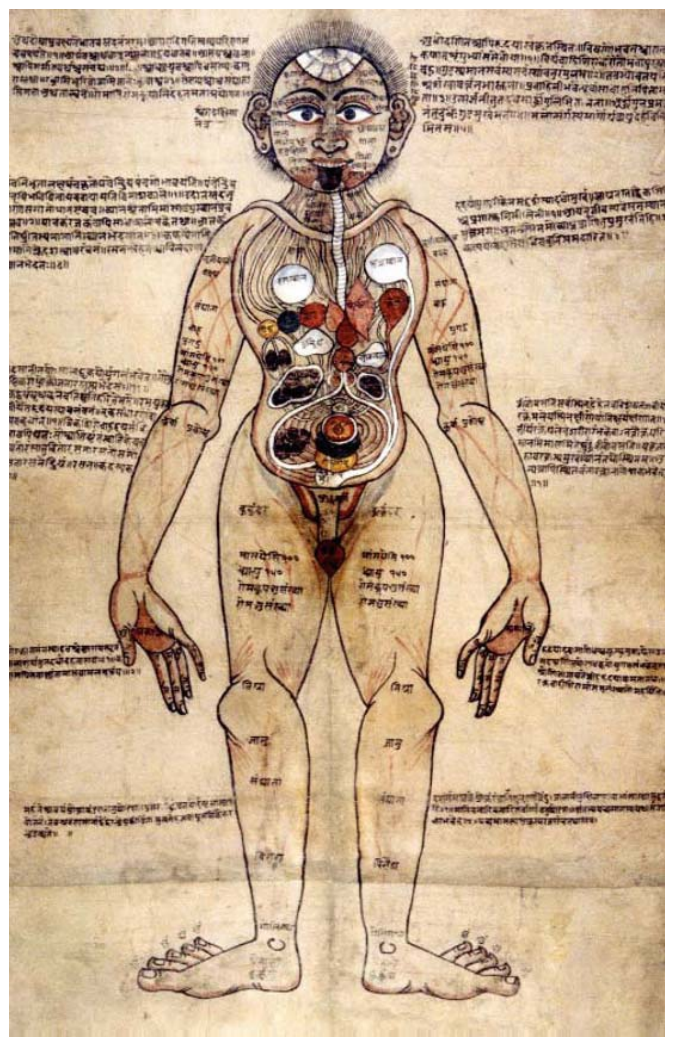

Figure 13. The Āyurvedic body, $c a$. eighteenth century, probably of Nepalese provenance. Wellcome IC \#574912i. Wellcome Library, London. 
It is important to emphasize that the image in Figure 13 really is unique. In studying thousands of Sanskrit manuscripts and paintings, I have never seen another image that even approaches it in theme or treatment. In fact, all Āyurvedic manuscripts I have studied have been empty of accompanying illustrative materials. There are small sketches of chemical apparatuses in some alchemical manuscripts, notably those of the Rasendramangala and some of the Rasaratnākara (Wujastyk 1984a). But no single manuscript I have seen contains even so much as an anamical sketch, a line drawing for surgical guidance, or any other visual representation of the medical body. This underlines the great importance of the image in Figure 13. It is possible that its provenance is Nepalese, although this is not certain. But, as is well known, some Sanskrit texts and traditions have survived in Nepal, whereas they have vanished in peninsular India. And the proximity of Tibet, where traditions of manuscript illustration are much stronger, may also be relevant. The Tibetan line drawing in Figure 14 shows bloodletting and moxibustion drawing points. The Tibetan text labels begin, "Those marked in red are bloodletting points and those marked in black ink are moxa points." Compare the treatment, especially hands and feet, with the Ayurvedic anatomical man in Figure 13. This evident continuity of artistic style suggests that the Indian/Nepalese figure was inspired to some extent by Tibetan traditions of body illustration.

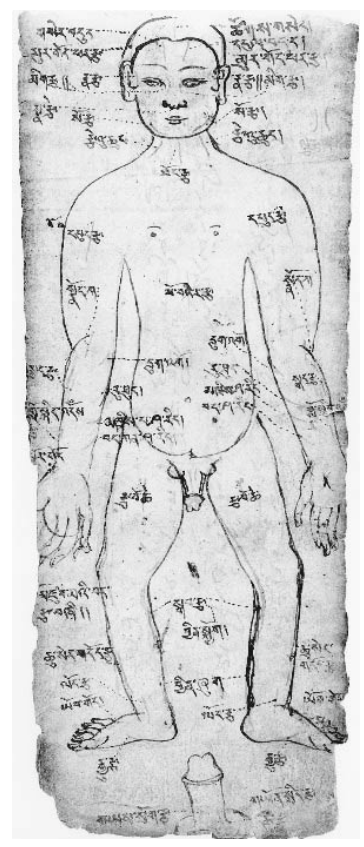

Figure 14. Tibetan drawing of bloodletting and moxibustion points, n.d. To be compared with Figure 13, especially the treatment of hands and feet. Wellcome Or. Tibetan chart 48(1). Wellcome Library, London. 
With the customary interest in itemization, the Ayurvedic literature is keen to enumerate the receptacles, ligatures, conduits, orifices, and tissues that can be found in the body. The Śärngadhara Saṃhitā offers a fairly standard and clearly presented version of such a list (Wujastyk 2003: 270-74). There are 7 receptacles (äśaya); 7 body tissues (dhātu); 7 impurities of the body tissues (dhātumala); 7 subsidiary body tissues (upadhātu); 7 membranes (tvac); 3 humors (doṣa); 900 sinews (snāyu); 210 ligaments (sandhi); 300 bones (asthi); 107 lethal points (marman); 700 ducts (sirā); 24 pipes (dhamanī); 500 muscles (māmsapeśî); 20 extra ones for women; 16 tendons (kandarā); 10 orifices of the male body; and 13 orifices of the female body. Although these items may not in all cases be organs in the modern biomedical sense, there is a definite sense that Āyurveda views the body as a locus of medical organs and processes that would be recognizable in general outline and principle to a modern anatomist.

The fluids in the body are transported from place to place by three principal types of conduit: ducts (sirā), pipes (dhamanī), and tubes (srota). Surprisingly little work has been done on clarifying what these conduits do and how they are explained in Âyurvedic theory (exceptions include Dasgupta 1969: chapter 13; Kutumbiah 1999: chapter 2). Chinese medical books abound in diagrams of the body carrying lines illustrating channels of chi, but no Indian book or manuscript to my knowledge shows maps of the ducts, pipes, or tubes.

According to the Suśruta Samhitā, the function of the 700 ducts is to carry wind, bile, phlegm, and blood around the body, starting from their "root" in the navel. In a vivid pair of metaphors, one agricultural and one botanical, Suśruta's text describes the ducts as follows:

There are seven-hundred ducts. This body is irrigated by these, just like a garden by water channels, and a field by ditches. And it is assisted by special contractions and expansions. Their ramifications are like those of the veins on the leaf of a tree. Their root is the navel. From there, they spread out upwards, downwards and horizontally (Suśruta Saṃhitā 7.3; Acharya 1915: 293; my translation).

A point of particular interest is that the ducts are colored according to what they carry:

In that context, those that carry wind are tawny; these ducts (sir $\bar{a})$ are filled with air. Because of bile they are hot and dark blue, and because of phlegm they are cool, white, and steady. Those ducts that carry blood are red, not too hot or too cool (Suśruta Saṃhitā 7.18; Acharya 1915: 294; my translation).

These distinctions seem likely to be based on the observation of different colored conduits under the surface of the skin.

The twenty-four pipes function in connection with the transportation of wind and resemble the Greek pneuma-carrying arteries of Praxagoras of Cos (Phillips 1973: 
137). In another botanical simile, Suśruta likens the pipes to the stem and stalk of the lotus plant, which have tiny holes (kha) in them (Suśruta Samhitā 9.10). The pipes arise from the navel. Ten travel upward and carry sense impressions, breath, speech, tears, and so forth. Ten travel downward and carry wind, urine, faeces, semen, menstrual blood, and so on. They also carry the juice of digested food to the upward directed pipes in the body, distributing nourishment. The remaining four pipes ramify into thousands of vessels, which lead to the hair follicles, and transport sweat outwards and oil, water, etc., inwards. They also function as carriers of sensation from the skin.

Finally, the twenty-two tubes carry breath (prāna), food (anna), water (udaka), flesh (māmsa), fat (medas), urine (mūtra), faeces (purīsa), semen (śukra), menstrual blood (ārtava), chyle (rasa), and blood (rakta). The pathways of these tubes in the body are very complex. They start and end in different places, sometimes connecting organs or receptacles, sometimes connecting with pipes (Suśruta Saṃhitā, śārīrasthāna 9).

It is interesting to note that in Suśruta's time there was controversy about all these conduits. The Suśruta Saṃhitā records a view that all these tubes, pipes, and ducts are in fact all the same thing. But the view is rejected on the basis of differences in appearance, source, and function (Suśruta Samhitā, śārīrasthāna 9). In the light of this ancient debate it is interesting to see that tubes are ignored by Śārngadhara.

\section{Persian Anatomical Images in India}

The Āyurvedic image of the human anatomy in Figure 13 is, as I have argued elsewhere, quite exceptional and may be among the very earliest medical images of the body in India (Wujastyk 2007). An estimated dating places the image in the early eighteenth century (Wujastyk 2008b). However, an exciting recent discovery has led to the recognition of a new type of indigenous medical painting in India, which may be as old as the image in Figure 13.

Medical historians have known for some time that there was a Persian tradition of anatomical illustration, commonly accompanying manuscripts of the anatomical work Tașrīh-i Manșūrī (French 1984; Savage-Smith 1997). This is the tradition of the so-called fünfbilder, or "Five-picture Series," following the early study by Karl Sudhoff (1907). In fact, as the series has become better known from more manuscripts, it has become clear that it consists of six, seven, or even more standard images. This anatomical illustration tradition is known from Persia, from the late fourteenth century, and there are many interesting features and questions associated with it, which have recently been discussed by Roger French (1984), Emilie SavageSmith (1997), and others. For the present purpose, however, it is sufficient for us to see one of these images, in order to recognize the main pictorial details of this tradition. Figure 15 shows an example. These figures typically face the viewer (although one of the other standard figures faces away), the legs are bent, the hands are on the thighs, the head is circular, and the internal organs, including intestines, are displayed and labeled with text. 


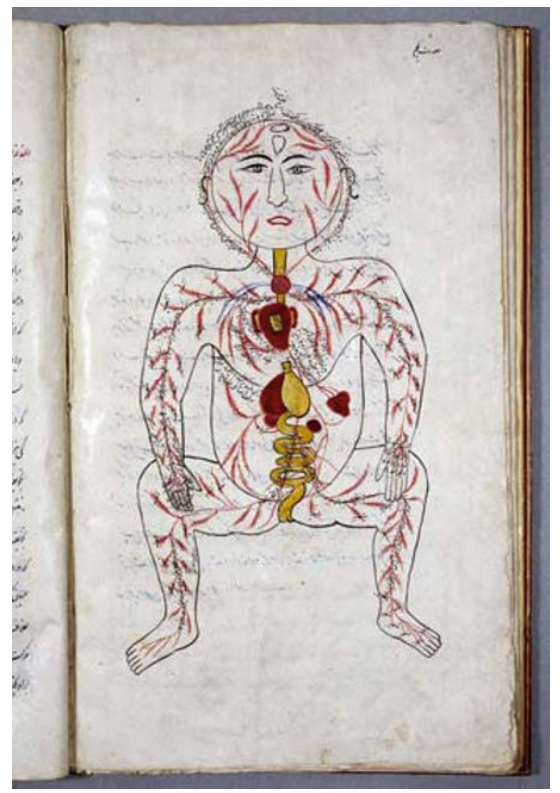

Figure 15. An anatomical image from Tașrīh-i Manșūrī tradition, nineteenth century. Wellcome Or. MS Persian 612. Wellcome Library, London.

After Islam, and especially the Mughal dynasty, had established itself decisively as a cultural power in the subcontinent, manuscripts such as these were copied in India as well as Persia and elsewhere. C. A. Storey (1958-[1997]: 2.226-28) lists a manuscript copy in Lahore. Indeed, it is likely that the image in Figure 15 was actually painted in India, since the bulk of the Wellcome Persian collection was acquired in India. However, documentation for the provenance of this particular manuscript is not available.

Having familiarized ourselves with the stylistic features of the Tașrīh-i Manșūri anatomical images, let us turn to a newly identified image of the same type, but in a Hindu setting (Figure 16). This image was first published in a study of Tantric art (Mookerjee 1982: 15). The image was identified as a Tantric image illustrating the "nā $\bar{d} \bar{\imath}$ s, subtle channels of the human body." However, an acquaintance with the Tașrīh-i Manșūrī series makes it immediately clear that Figure 16 is an adaptation derived from the Persian tradition of anatomical illustration. It is a medical not a Tantric image. The image does not illustrate nâdīs, but the veins, arteries, and intestinal tract. The text surrounding the image is old Gujarati, which places the image in Western India. The painting was formerly in the Hamburg collection of Jan Wichers, but has recently come into the collection of the Wellcome Library in London. The text and image await detailed study, but it is plain that the text presents a mixture of ideas from medicine and the Tantric view of the body. The text labels on the body are a mixture of Sanskrit medical names and Persian names in both 
Persian and Devanagari scripts. In spite of the purely medical and non-Indian background of the Tașrīh-i Manșūrī tradition which clearly inspired the Indian image, it does appear that cakras have been added to the spinal column, albeit very faintly and imperfectly. This suggests that the Indian artist may have felt impelled by his artistic and cultural background to Indianize the image by assimilating it, in a limited way, to the normal type of cakra/meditator image.

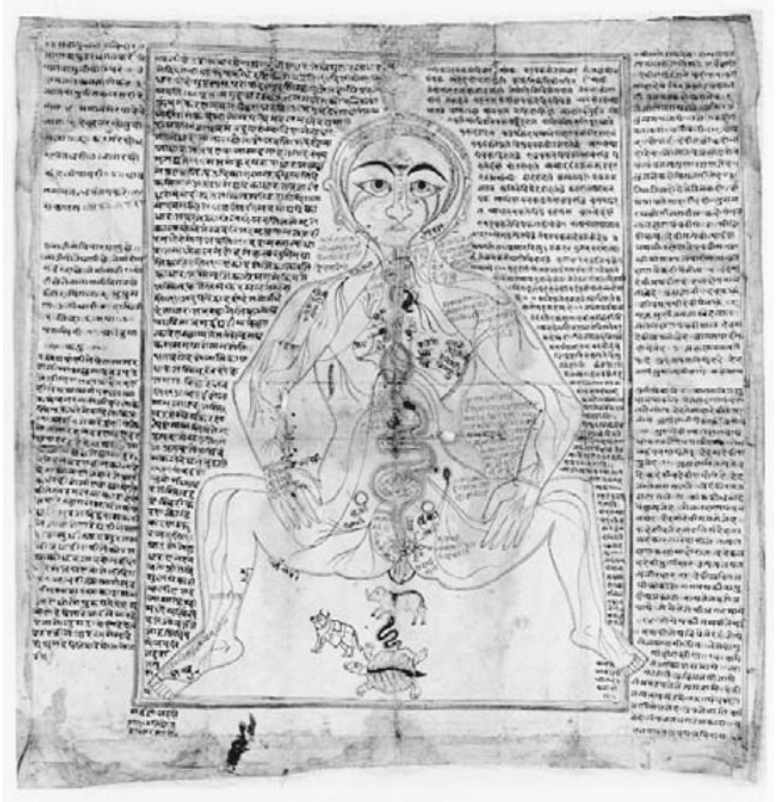

Figure 16. Indian anatomical painting, about eighteenth century, Western India. In the Taṣrīh-i Manșūrī style, but in an old-Gujarati manuscript. Wellcome MS Indic $\delta 74$. Wellcome Library, London.

The image in Figure 16 is not dated, but may be placed to approximately the same period as the Nepalese anatomical painting, if not slightly earlier. If it is earlier, then it is the first Hindu anatomical painting known from the Indian subcontinent.

\section{Print and Western Anatomy}

In the mid-nineteenth century, the Tașrīh-i Manșūrì began to appear in print in India, with editions known from Delhi in 1848 and Lahore in 1878 (Storey 1958-[1997]: 227). This period also saw an intensification of the Indian medical encounter with European anatomical learning and traditions, which were appearing in India in European medical books and teaching. Many European medical publications, for example, are known to have entered the personal library of the Mahārāja Serfojī II of Thanjavur (1798-1832), since they appear in the catalogue of his collection (Perumal 1989: 59-76). And evidence of early anatomical teaching in Calcutta is 
present in the publications of Peter Breton (1825) and the other staff members of the Native Medical Institution in Calcutta. The Indian response to these new foreign influences was variously accommodation, adaptation, absorption, and, later, syncretism.

Illustrations of the Āyurvedic body began to appear in print from the late nineteenth century. These evidenced the beginnings of a more widespread indigenous attempt at anatomical illustration. An important innovator in this respect was Muralidhara Sharma (see Figure 17). Sharma was royal physician at the court of Farrukhabad. In 1898, in a seminally important collaboration with the publisher Khemaraja Srikrsnadasa at the Srivenkatesvara Press in Bombay, Sharma produced an edition of the Suśruta Samhitā that was graced with an unprecedented number of very interesting medical images. These images have continued to be reproduced not only in reprints of Sharma's edition, but also in editions of many other Āyurvedic medical texts right up to the present, but almost always without attribution.

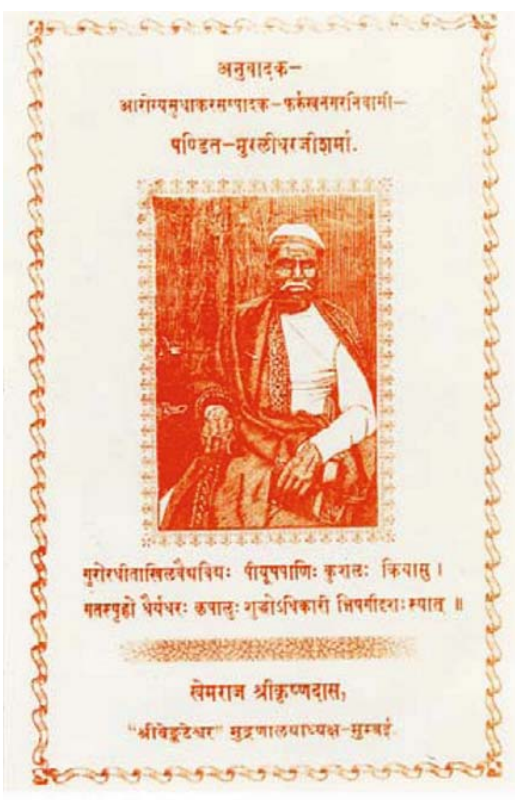

Figure 17. Rājavaidya Muralidhara Sharma of Farrukhabad, about 1895. From the frontpiece of Sharma's edition of the Suśruta Samhitā (1895-99: iv). Wellcome P.B.Sansk.187. Wellcome Library, London.

What was Sharma seeking to achieve? His introduction does not mention the illustrations, so we must deduce what we can from the images themselves. They contain a mixture of elements from various traditions. The digestive tract, for example, in Figure 18, has a carefully labeled drawing of the organs, and the accompanying text is keyed to the labels with explanations in Hindi and technical terms in English. This is clearly an attempt to provide a syncretic view of the human anatomy. For Sharma, 
it was still possible that the Āyurvedic and "English" (angrezi) medical systems could share, unite, and provide a true explanation of the body. In fact, while Figure 18 and many of the other images appear to be original artwork, the two standing figures in Figure 19 seem to have been copied from a Western anatomical sourcebook. For Sharma, it appears, there was no real distinction between Āyurvedic and English anatomy. Both were valid, and they could be unproblematically synthesized. One of the surprising elements in Sharma's edition is the absence of polemics. The edition is offered as a useful and attractive working tool for the scholar and physician, as the publisher repeatedly emphasizes in his forewords.

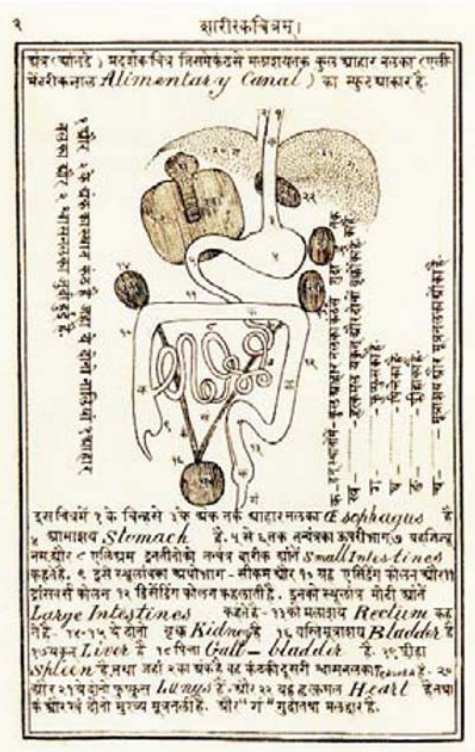

Figure 18. The digestive tract, from Muralidhara Sharma's edition of the Suśruta Samhitā (1895-99, 2: 2).

Wellcome P.B.Sansk.187.

Wellcome Library, London.

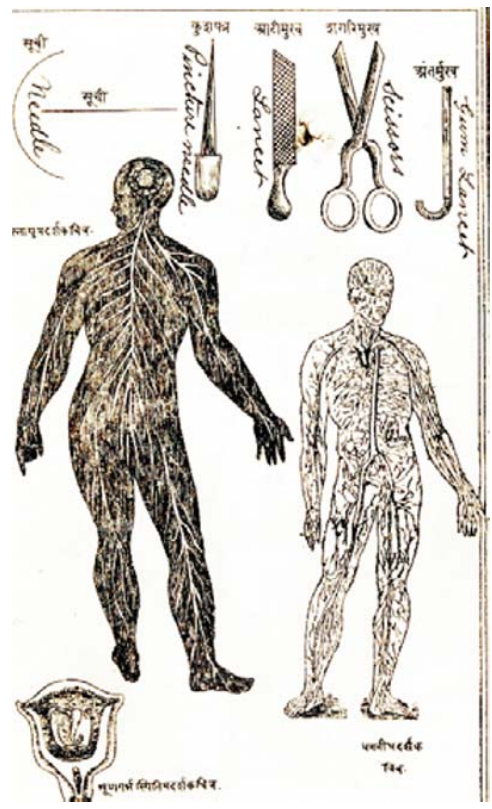

Figure 19. Surgical instruments, the sinews (snāyu, left) and pipes (dhamani, right) and a gravid uterus, from Muralidhara Sharma's edition of the Suśruta Samhitā (1895-99, 1: 3). Wellcome P.B. Sansk.187. Wellcome Library, London.

A limited amount of further insight into Sharma's intellectual orientation is provided by a book he produced on the topic of plague (Sharma 1899). In his introduction, Sharma noted that:

This pamphlet about the origin of Plague and its [c]ure has been prepared on the 


\section{4 / Dominik Wujastyk}

basis and references of most of the learned and experienced Vaids; and in the proofs the shloks (śloka) of the worthy and much valued old Sanscrit Vaidic books are given; and it is proved also with the discussion and experience according to present age. Every body can undoubtedly know how higher and prosperous was the enquiry and experience of the old Indian Vaids and how many good things are found buried often from the Indian Sanscrit Vaidic knowledge (1899: n.p.).

Sharma appears from these sources to be a physician deeply versed in the classical Sanskrit literature of Āyurveda, deeply enough to produce an edition and bhās $\bar{a}$ (Hindi) translation of the Suśruta Samhitā. However, he felt it important to enhance this edition with a series of illustrations, some originated by himself or the Srivenkatesvara Press and some sourced from European anatomical textbooks (and ultimately from Vesalius). He therefore felt that he had a role as a modernizer or at least that he could show the relevance of Āyurveda to the contemporary European medicine of the late nineteenth century that he saw around him. His plague tract was published in Bombay in 1899, the year after the Bombay outbreak of bubonic plague in 1896-98, part of the Third Plague Pandemic. Once again, his introduction presents the idea of an age of great knowledge in India's past and of its relevance and importance in meeting contemporary health problems. ${ }^{5}$ Sharma's work as a whole is of value in the context of the history of reception of and response to nineteenth-century European medicine in India.

Things were different by 1913, when Gananath Sen (b. 1877) started to publish his Pratyakșáāīira, or "The Body Revealed" (1913-22). As Figures 20 and 21 show, the anatomical illustration has now been decisively acculturated to that of the Western tradition. Sen wrote this work, and others like his Siddhāntanidānam (1966), in Sanskrit as a deliberate act aimed at reaching as wide a medical audience as he could. In his introduction to the Pratyaksaśāīra he explains that Sanskrit was still the lingua franca of traditional medical learning and practice and the most effective means of reaching a really wide readership in both North and South India. His book was indeed very influential and widely known, and its reputation was enhanced by the numerous illustrations that accompanied the text.

Sen stated that he was influenced by the studies of A. F. Rudolf Hoernle (1907) on the osteology of ancient India and that he was committed to developing an indigenous nomenclature for anatomical description, using Sanskrit as the wellspring of verbal roots just as Greek was plundered for scientific terminology in Europe. Sen also combined these goals with a nationalist agenda of recovering India's ancient glory through the study and development of her own anatomical and medical traditions. In 1932 he founded the syncretic Viśvanātha Āyurveda Mahāvidyālaya. ${ }^{6}$

A few years later, a similar initiative took place in South India. P. S. Varier (18691944) had begun his education in medicine with Aștavaidyan Śrī Kuttancheri Vasudevan Mooss, a high-caste Āyurvedic teacher in Kerala (Nair 1954: 14-17). After four difficult and, apparently, unhappy years learning Āyurveda, he moved to the coast and took up an intense three-year personal apprenticeship to an English- 


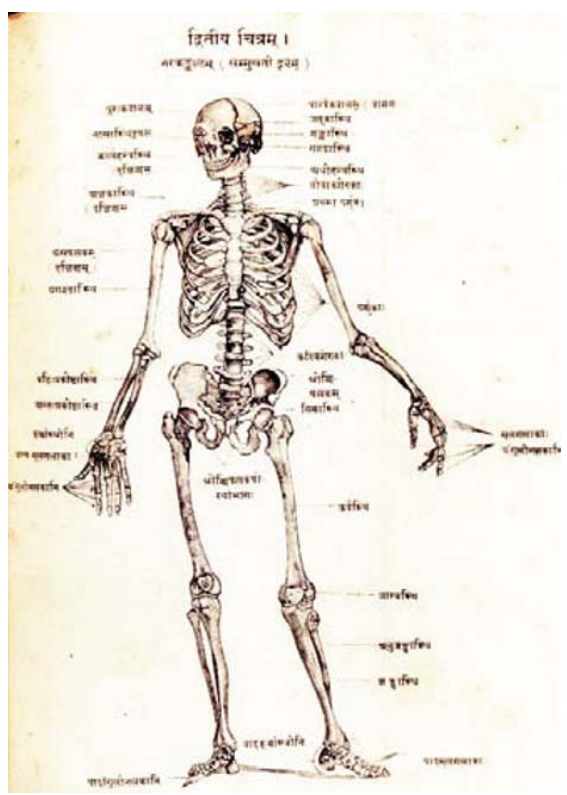

Figure 20. The human skeleton, with Sanskrit labels. From Gananath Sen's Pratyakșaśārīram (1913-22). Wellcome Library, London.

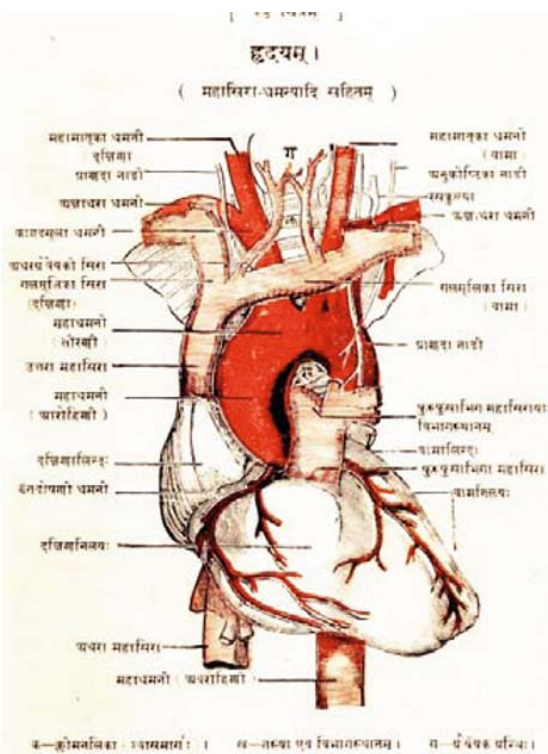

Figure 21. The heart, with Sanskrit labels. From Gananath Sen's Pratyakșaśārīram (1913-22). Wellcome Library, London. 
trained surgeon, V. Varghese, later the chief medical officer of Cochin State (Nair 1954: 18-25). On return to his village after this period, Varier set up a modest medical practice, using the skills he had learned. But before long, the chief prince of the village, who was hostile to him and his family, publicly reprimanded him and threatened him with imprisonment, for prescribing allopathic medicines without a licence (Nair 1954: 27). Obliged to abandon the practice of English medicine, Varier fell back on his Āyurvedic training, but began introducing innovations to his practice based on good ideas taken from his English medical experience. Chief among these was the idea of standardized, bottled compounds. This and other innovations produced by the company he founded in 1902, Arya Vaidya Sala, made him rich. ${ }^{7}$ By the 1920s Varier was a prominent citizen and in a position to take up a new initiative. This he did, publishing his Aștāñgaśārīram in 1925 and his Bṛhacchārīram "Great Anatomy" in 1942. These works shared the goals of Sen's earlier Calcutta publications. They were written in Sanskrit, were scientific, precise, syncretic, and heavily illustrated. The Sanskrit title-page of the Bṛacchärîram included the English explanation: "An up-to-date and detailed work on human anatomy and physiology in Sanskrit combining the ancient and modern knowledge on the subject with various illustrations and coloured plates."

Zimmermann (1978) has focussed attention rightly on the epistemological dissonance that is evident in these works; but perhaps because of this very dissonance, they made great strides in the medical illustration of Indian medical texts, even though they were hybrid, syncretic texts.

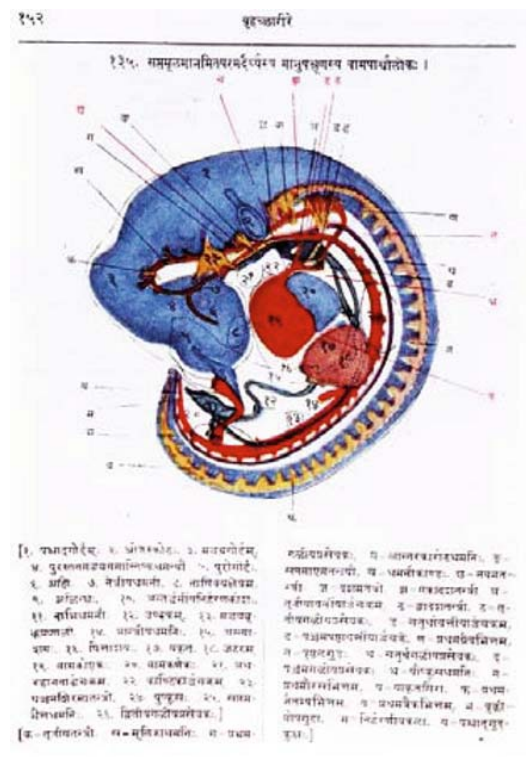

Figure 22. An embryo, with Sanskrit exposition. From P. S. Varier's Brhacchārīram (1988). Wellcome Library, London. 


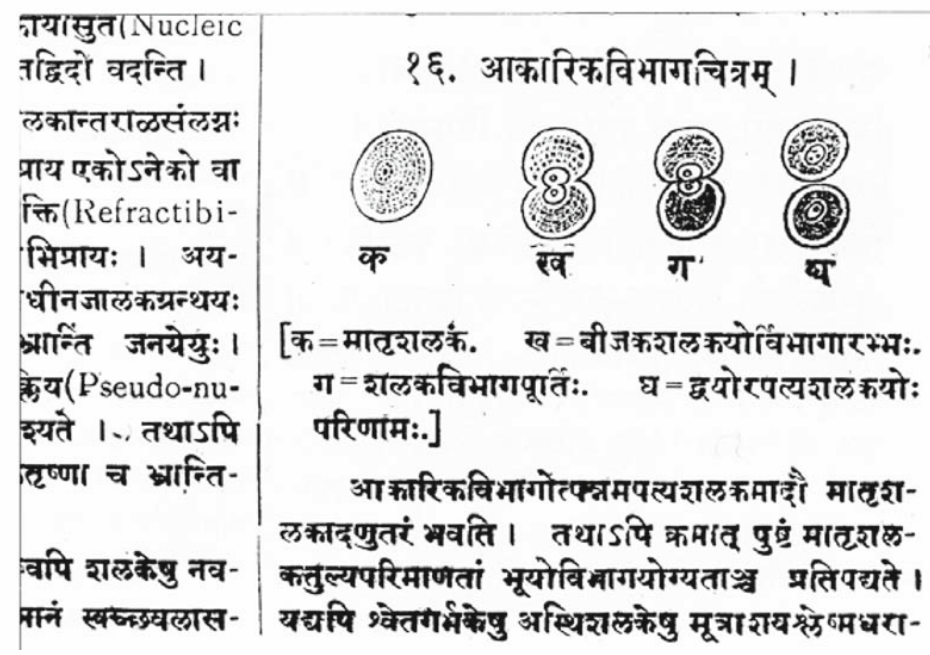

Figure 23. Cell division, with Sanskrit exposition. From P. S. Varier's Bṛhacchārīram (1988: 152). Wellcome Library, London.

\section{The Divergence of Medical Body Narratives}

The syncretic work of Sen and Varier at the beginning of the twentieth century was earnest, ideologically informed, and the product of real learning both in Sanskritic Ayurveda and in anatomy.

But already the attempt to create a meaningful anatomical picture of the human being out of both Āyurvedic and Western traditions, however theoretically unsound, was being abandoned in other quarters. In its place was, and remains, a deeply flawed epistemological situation in which two quite different and essentially incompatible anatomical models of the body are held in mind at once, in acquiescence to a schismatic worldview. This is well illustrated by the edition of the Sárngadhara Saṃhitā (Shastri 1931). The editor of this work, Parasurama Shastri, abandoned any attempt or even pretence of using body images meaningfully in his text. The edition he produced fell back on a merely iconic use of anatomical illustrations. This reminds us very much of the practice of the very earliest book illustrations known from India in which images of the Buddha were added to Prajñāpāramitā manuscripts to provide them with magical power and protection (Losty 1982: 24). But these images had no more narrative connection with the surrounding text than do the anatomical images in Shastri's edition.

In Figure 24 we see an illustration of a skeleton that at first glance appears to be part of the presentation of medical information in the book. But a closer examination reveals that the lines pointing to parts of the figure end in stubs with no labels or keys. In fact, the picture has simply been cut out of some other book and pasted into the edition, with all the contextual information - the actual meaning of the imageleft behind. The final irony is that the Sanskrit text surrounding the image of the 
skeleton is not concerned with the topic of bones or skeletons; it is discussing humors, ducts, pipes, and other topics.

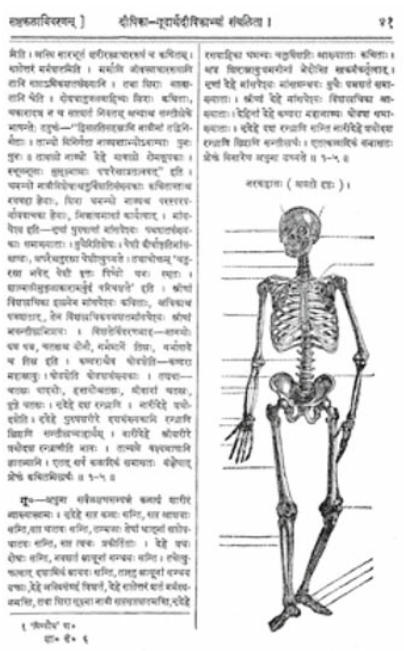

Figure 24. A skeleton image with merely iconic value. From Parasurama Shastri’s edition of the Śärngadhara Saṃhitā (1931:41).

Figure 25 is another illustration of the same phenomenon; this time the pictures of the digestive tract, etc., do have labels, using Sanskrit letters. But these are not referenced in the text; nor is there a key. Once again, the images are irrelevant and unconnected to the text in any meaningful manner.

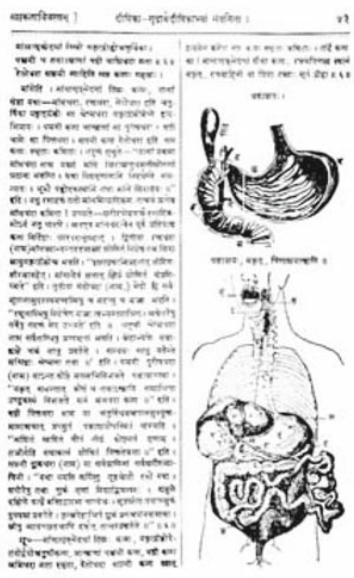

Figure 25. Internal organs. From Parasurama Shastri's edition of the Śārngadhara Saṃhitā (1931: 43). 
Finally, in Figure 26, we see an anatomical-type figure, illustrating a verse of the text that is discussing the pipes (dhamanī) in the body. The figure even has a correct title to this effect. But now we can see exactly where the image came from. A brief reference to Sharma's 1898 edition of the Suśruta Saṃhitā, Figure 19, confirms that this edition is recycling a figure from the nineteenth century, with no change, again stripped of contextual meaning. If confirmation were needed that a serious engagement with comparative anatomy had been abandoned, one need only notice that Shastri's edition labeled this diagram as illustrating the pipes, whereas in its original setting in Sharma's edition, it is an illustration of the sinews (snāyu).

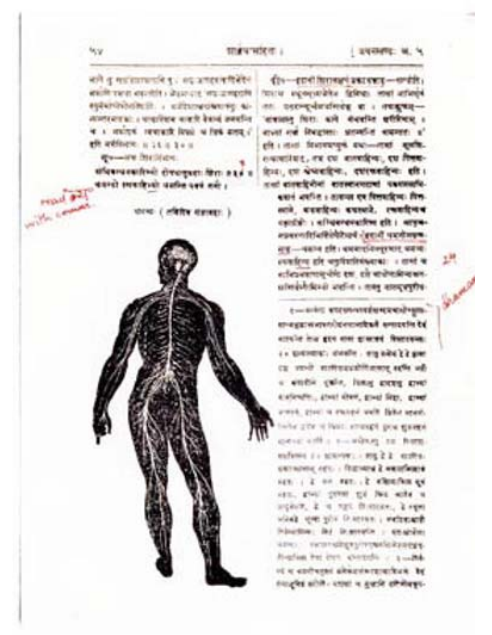

Figure 26. Anatomical figure labeled "pipes (dhamanyah)," illustrating conduits in the body. From Parasurama Shastri's edition of the Śarngadhara Saṃhitā (1931: 54).

The abandonment of any attempt at comparative and observational anatomy in the Shastri edition is coupled with a scientism in the editor's explanation of respiration, on which I have commented elsewhere (Wujastyk 2003: 259-60). Shastri (1931) reads a reference to "oxygen" into this Sanskrit text, which was composed around 1350. This combination of elements, that is, the loss of interest in observation and comparative anatomy and the rise of fanciful scientistic readings of the premodern texts, is a development that has continued to the present time. Meulenbeld (2008) recently analyzed just such developments in the case of the power-substance ojas. Jayanta Bhattacharya (2008) has argued that a de-mythologization of the Āyurvedic body under the influence of colonial epistemic hegemony took place and led to a new, rational and victorious medical paradigm of human anatomy among Āyurvedic physicians. But this view ignores the epistemic duality that has pervaded Āyurvedic thinking since the mid-twentieth century.

Stark examples of this duality are routinely provided by the qualifying examina- 
tions that Āyurvedic students sit even today. The Model Papers for Ayurvedic Competitive Exams edited by G. Prabhakara Rao (1994) includes juxtapositions such as those in Figure 27. ${ }^{9}$ In the top example, question 50 assumes the fundamental worldview of the fully classical Āyurvedic body in which all movement is caused by forms of wind, that is, the body is moved by pneumatic force, and this is known through the authoritative assertions of ancient Sanskrit texts perhaps coupled with the consequent conditioned observation. But question 51 requires knowledge that arises from a quite other epistemic realm, from laboratory practice that assumes the existence of red blood cells and an acquaintance with the technology needed to measure the proportion of such cells in plasma. In the lower example, question 50 presupposes a model of the body in which the digestion of food takes place in a digestive fire (agni), and this may be affected in various ways by the three humors (vāta, pitta, and kapha). The following two questions deal with concepts of hormonal secretion and urine production that assume the worldview of modern establishment medicine, a worldview that uses terminology, methods, and fundamental assumptions that are theoretically at odds with the body controlled by fire, wind, bile, and phlegm.

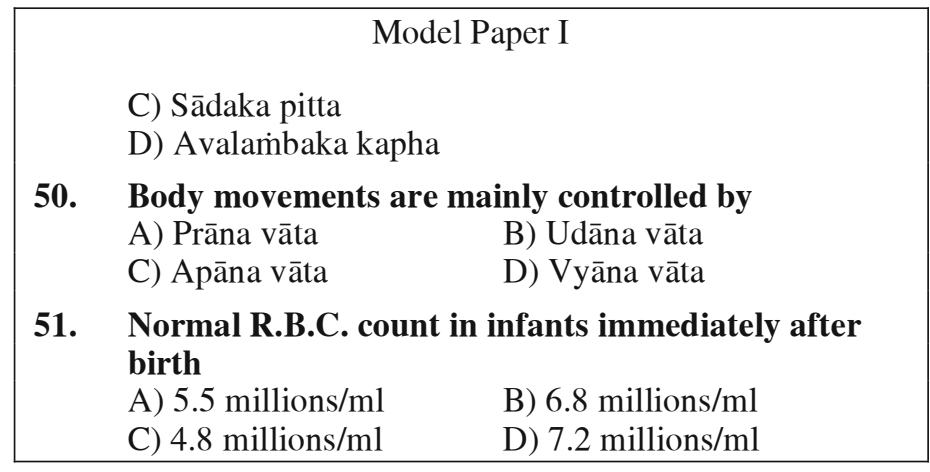

210 Model Papers for Āyurvedic Competitive Examinations

50. Which of the following is not true in case of Agni
A) Vișamāgni is due to Vāta predominance
B) Tìkṣnāangni is bue to pitta predominance
C) Samāgni is due to Kapha predominance
D) None of the above

51. Vasopressin is Secreted by
A) Thalamus
C) Liver
B) Hypothalamus
D) Kidney

52. The process requires for urine formation
A) Glomerular filtration
B) Tubular reabsorption
C) Tubular secretion
D) All the above

Figure 27. Some model Āyurvedic examination questions (Rao 1994: 7, 210). 
The late nineteenth and early twentieth-century efforts by Indian Āyurvedic physicians and publishers to provide a new descriptive and visual narrative of the human body that took account of both Āyurvedic tradition and European knowledge represented the birth of a genuine and internalized form of modernity. These efforts were integrative in thrust and sought to develop a new and unified account of human physical embodiment that was meaningful for practising physicians in the tradition of Āyurveda. This account was profoundly traditional and often expressed in Indian languages, including Sanskrit. Yet it incorporated, adapted, and absorbed new knowledge to produce anatomical accounts such as those of Sen and Varier. These may appear surprising but they can be appreciated without engendering disabling levels of cognitive dissonance. These modernizing efforts also produced large-scale linguistic efforts to produce a new Sanskrit vocabulary for medicine and anatomy, enriching and adapting traditional terms and using newly coined compound words to express the new medical knowledge. In the later twentieth century, these efforts were pushed aside by a wholesale espousal of Western models of bodily knowledge that paid only superficial homage to Āyurvedic forms that in fact remained unassimilated and alien even within India. ${ }^{10}$ The Āyurvedic practitioner's curriculum, standardized in the 1970s and still in force today, continues to inculcate this epistemological split. In the words of two contemporary Āyurvedic practitioners and researchers,

From one perspective, the inner state of Ayurveda [today] is a picture of struggle to establish its epistemological identity and retain its integrity. From another, it is a picture of unhappy compromise with modern medicine seeking justification in terms of modern medical theory and its parameters, and trying unsuccessfully to prove itself to be scientific (Shankar and Manohar 1995: 104).

Whether the epistemological tensions faced by Āyurvedic practitioners find a resolution in the future remains a matter for epistemological reflection, social action, and educational reform. But from the point of view of body image, the science remains at present fundamentally fractured, incapable since the mid-twentieth century of producing coherent new visual representations that are organically evolved from its own deep cultural past.

\section{Notes}

1. An earlier version of this paper was published in French as "Interpréter l'image du corps humain dans l'Inde pré-moderne" (Wujastyk 2002), and material from that publication is reproduced here by kind permission of CNRS Éditions. Images are (C) Dominik Wujastyk unless otherwise stated.

2. The Hermetic postulate first appears in European thought in the Emerald Tablet of Hermes Trismegistus, a text that itself first appears in the second half of the first millennium (Ruska 1926; Manzalaoui 1974). 
3. puruṣo’yam lokasaṃmitah...yāvanto hi loke (mūrtimanto) bhāvaviśeșās tāvantah puruṣe, yāvantah puruṣe tāvanto loke I Compare Caraka Saṃhitā 4.13 where the same homology is presented.

4. Reviewed in Wujastyk 2004. The five volumes of this extraordinary survey contain over four thousand pages with 36,600 footnotes, and the general index does not even contain the word acupuncture, although the fascinating historical links between Āyurveda and Chinese medicine are explored in several places.

5. Sharma's introduction continued with a survey of the contents of his tract: "The following are the contents of the pamphlet. 1. The prayer of God and beginning of pamphlet 2. The sorts of Plague 3. Discussion on Plague 4. The reason of present prevailing Plague 5. How the poison touches the body 6. Symptoms of the Plague 7. Declaration of insects in the poison of Plague 8. When and why the poison blooms 9. Condition of curable and incurable dicease 10. Evident proofs 11. Cause of prevailing Plague 12. Beginning of cure 13. Methods to save from Plague 14. Remedies if done at one place become useful to many 15. Medicines and cures for plague effected 16. Differences in symptoms of Plague effected 17. Method of purifying the air and the earth from poison of Plague."

6. Gupta (1976) and Leslie (1992) studied Sen's pivotal role in the development of Āyurvedic modernity. Arnold (2000: 176-85) provides a general overview of $\bar{A} y u r v e d i c$ revivalism at this period.

7. The Keraleeya Ayurveda Samajam of Shoranur (www.samajam.org) claims priority as the earliest professional association of Āyurvedic practitioners.

8. On Varier's life, the anodyne biography by Krishnankutty (2001) supplements but does not supercede Nair (1954).

9. Compare also the model questions reproduced by Wujastyk and Smith (2008: Introduction, 7-8).

10. For an account of the formation of Indian government policy regarding education in Āyurveda, see Wujastyk (2008a).

\section{References Cited}

Acharya, Jadavji Trikamji, ed. 1981 [1941]. Carakasaṃhitā, śrīcakrapāṇidattaviracitayā āyurvedadīpikāvyakhyayā saṃvalitā. New Delhi: Munshiram Manoharlal.

Acharya, Yadavasharma Trivikrama, ed. 1915. Suśrutasaṃhitā Suśrutena viracitā, Vaidyavaraśrị̄alhaṇācāryaviracitayā Nibandhasamgrahākhyavyākhyayā samullasitā, Ācāryopāhvena Trivikramātmajena Yādavaśarmaṇā saṃśodhitā. Bombay: Nirnayasagaramudrayantralaye.

Alter, Joseph S. 1997 [1992]. The Wrestler's Body, Identity and Ideology in North India. New Delhi: Munshiram Manoharlal.

Arnold, David. 2000. Science, Technology and Medicine in Colonial India. Cambridge: Cambridge University Press.

Basham, A. L. 1967 [1954]. The Wonder That was India. London: Sidgwick \& Jackson. 
Bhattacharya, Jayanta. 2008. "Encounter in Anatomical Knowledge: East and West." Indian Journal of History of Science 43, 2: 163-209.

Bouy, Christian. 1994. Les natha-yogin et les Upanisads: étude d'histoire de la littérature hindoue. Paris: Boccard.

Breton, Peter. 1825. A Vocabulary of the Names of the Various Parts of the Human Body and of Medical and Technical Terms in English, Arabic, Persian, Hindee and Sanscrit for the Use of the Members of the Medical Department in India. Calcutta: Government Lithographic Press.

Briggs, George Weston. 1982 [1938]. Gorakhnāth and the Kānphața Yogīs. Delhi: Motilal Banarsidass.

Caillat, Colette. 1981. La cosmologie jaina (ed. Ravi Kumar). Paris: Éditions du Chêne.

Daniélou, Alain. 1991 [1964]. The Myths and Gods of India: The Classic Work on Hindu Polytheism. Rochester: Inner Traditions.

Dasgupta, Surendranath. 1969 [1932]. A History of Indian Philosophy. Volume 2 of 5. Cambridge: Cambridge University Press.

Deshpande, S. H. 1992. Physical Education in Ancient India. Varanasi: Bharatiya Vidya Bhavan.

Dissanayake, Wimal. 1993. "Self and Body in Theravada Buddhism: A Tropological Analysis of the Dhammapada." In Thomas P. Kasulis, Roger T. Ames, and Wimal Dissanayake, eds., Self as Body in Asian Theory and Practice, 123-45. Albany: State University of New York Press.

Dundas, Paul. 1992. The Jains. London: Routledge.

Eliade, Mircea. 1970 [1954]. Yoga: Immortality and Freedom (trans. Willard R. Trask). Princeton: Princeton University Press.

Farquhar, J. N. 1925. "The Fighting Ascetics of India.” Bulletin of the John Rylands Library 9, 2: 431-52.

Fedorova, Mariana. 1990. Die Marmantheorie in der klassischen indischen Medizin. Ph.D. dissertation. Munich: Ludwig-Maximilians-Universität Library.

Filliozat, Pierre-Sylvain 1999. "Homologies du monde, de la parole et de l'homme dans les religions de l'Inde (des Veda aux Tantra)." In Philippe Gignoux, P.-S Filliozat, M. Tardieu, J.-D. Dubois, and M.-J. Pierre, eds., Ressembler au monde: nouveaux documents sur la théorie du macro-microcosme dans l'antiquité orientale, 11-40. Turnhout: Brepols.

Flood, Gavin D. 1993. Body and Cosmology in Kashmir Śaivism. San Francisco: Mellen Research University Press

Fox, Nick J. 1997. "Is There Life After Foucault? Texts, Frames and differends." In Alan Petersen and Robin Bunton, eds., Foucault, Health and Medicine, 31-50. London: Routledge.

French, Roger. 1984. "An Origin for the Bone Text of the 'Five-figure Series'." Sudhoffs Archiv 68, 2: 143-56.

Gombrich, Richard F. 1996. "Foreword." In Sue Hamilton, Identity and Experience: The Constitution of the Human Being according to Early Buddhism. London: 
Luzac Oriental.

Goudriaan, Teun and Sanjukta Gupta. 1981. Hindu Tantric and Śākta Literature. Wiesbaden: Otto Harrassowitz.

Grosz, Elizabeth. "Inscriptions and Body-Maps: Representations and the Corporeal." In T. Threadgold and A. Cranny-Francis, eds., Feminine/Masculine and Representation, 62-74. Sydney: Allen and Unwin.

Gupta, Brahmananda. 1976. "Indigenous Medicine in Nineteenth- and Twentiethcentury Bengal." In Charles Leslie, ed., Asian Medical Systems: A Comparative Study, 368-78. Berkeley: University of California Press.

Gupta, Sanjukta, Dirk Jan Hoens, and Teun Goudriaan. 1979. Hindu Tantrism. Leiden: E.J. Brill.

Hamilton, Sue. 1995. "From the Buddha to Buddhaghosa: Changing Attitudes Toward the Human Body in Theravāda Buddhism." In Jane Marie Law, ed., Religious Reflections on the Human Body, 46-63. Bloomington: Indiana University Press. Hamilton, Sue. 1996. Identity and Experience: The Constitution of the Human Being according to Early Buddhism. London: Luzac Oriental.

Heilijgers-Seelen, Dory. 1990. "The Doctrine of the Șatcakra according to the Kubjikāmata." In Teun Goudriaan, ed., The Sanskrit Tradition and Tantrism, 5665. Leiden: E.J. Brill

Hoernle, A. F. Rudolf. 1907. Studies in the Medicine of Ancient India: Osteology or the Bones of the Human Body. Oxford: Clarendon.

Hooper, Robert. 1801 [1797]. The Anatomist's Vade-Mecum: Containing the Anatomy and Physiology of the Human Body. Boston: David Carlisle.

Hopkins, Edward Washburn. 1895. The Religions of India. Boston: Ginn.

Jordens, J. T F. 1998 [1978]. "A Fake Autobiography.” In J. T. F. Jordens, Dayananda Saraswati: His Life and Ideas, 179-81. New Delhi: Manohar.

Kapani, Lakshmi. 1989. "Upanisad of the Embryo and Notes on the GarbhaUpanisad." In Michel Feher, with Ramona Naddaff and Nadia Tazi, eds., Fragments for a History of the Human Body, 3.177-96. New York: Zone Books.

Keith, Arthur Berriedale. 1925. The Religion and Philosophy of the Veda and Upanishads. Volume 2 of 2. Cambridge: Harvard University Press.

Kiñjavaḍekara, Ramachandrashastri, ed. 1990 [1938-40]. Aștāingasañgrahah mūlasūtrāṇi śaśilekhātīkā tupțippaṇī, śarīrapariśiștam așṭāngahṛdayaśārīram, śārīrakoṣthakāni, śārīracitrāṇi, sūtra-śabda-viṣayasūcyah, viṣayapraveśah nivedanam, ityādibhih samvvalitam. 3 volumes. Poona: Citrasala Mudrandlaya. Delhi: Sri Satguru Publications.

Krishnankutty, Gita. 2001. A Life of Healing: A Biography of Vaidyaratnam P. S Varier. New Delhi: Viking.

Kumar, Anil. 1998. Medicine and the Raj: British Medical Policy in India, 18351911. New Delhi: Sage Publications.

Kutumbiah, P. 1999 [1962]. Ancient Indian Medicine. Bombay: Orient Longman.

Lakoff, George and Mark Johnson. 1980. Metaphors We Live By. Chicago: University of Chicago Press. 
Larson, Gerald James and Ram Shankar Bhattacharya, eds. 2008 [1970]. Yoga: India's Philosophy of Meditation. Delhi: Motilal Banarsidass

Leslie, Charles. 1992. "Interpretations of Illness: Syncretism in Modern Ayurveda." In Charles Leslie and Allan Young, eds., Paths to Asian Medical Knowledge, 177208. Berkeley: University of California Press.

Losty, Jeremiah. 1982. The Art of the Book in India. London: The British Library.

Lupton, Deborah. 1994. Medicine as Culture: Illness, Disease and the Body in Western Societies. London: Sage Publications.

Malamoud, Charles. 1996 [1989]. "Paths of the Knife: Carving up the Victim in Vedic Sacrifice." In Charles Malamoud, Cooking the World: Ritual and Thought in Ancient India (trans. David White), 169-80. Delhi: Oxford University Press.

Manzalaoui, M. A. 1974. "The Pseudo-Aristotelian Kitāb Sirr al-Asrār: Facts and Problems." Oriens 23-24: 147-257.

Meulenbeld, G. Jan. 1999-2002. A History of Indian Medical Literature. 5 volumes. Groningen: Egbert Forsten.

Meulenbeld, G. Jan. 2008. "The Woes of Ojas in the Modern World." In Dagmar Wujastyk and Frederick M. Smith, eds., Modern and Global Ayurveda: Pluralism and Paradigms, 157-76. Albany: State University of New York Press.

Mitra, Rajendra Lal. 1876. "On Human Sacrifices in India." Journal of the Asiatic Society of Bengal 45, 1: 76-118.

Mookerjee, Ajit. 1982. Kundalini: The Arousal of the Inner Energy. London: Thames and Hudson.

Nair, Kizhedath Vasudevan. 1954. A Biography of Vaidyaratnam P. S Varier. Kottakal: Arya Vaidya Sala.

Olivelle, Patrick, trans. 1998. The Early Upaniṣads. New York: Oxford University Press.

Padoux, André. 1990. "The Body in Tantric Ritual: The Case of the Mudras.” In Teun Goudriaan, ed., The Sanskrit Tradition and Tantrism, 66-75. Leiden: E.J. Brill.

Perumal, P., ed. 1989. A Catalogue of Serfoji's Personal Collection and Other Rare Books. Thanjavur: TMSSM Library Society.

Phillips, Eustace Dockray. 1973. Greek Medicine: Philosophy and Medicine from Alcmaeon to the Alexandrians. London: Thames and Hudson.

Rao, G. Prabhakara. 1994. Model Papers for Ayurvedic Competitive Examinations. Varanasi: Chaukhambha Sanskrit Bhavan.

Rawson, Philip. 1973. The Art of Tantra. London: Thames and Hudson.

Ros, Frank. 1994. The Lost Secrets of Ayurvedic Acupuncture. Twin Lake: Lotus Press. Roşu, Arion. 1981. "Les marman et les arts martiaux Indiens." Journal asiatique 269: 417-51.

Ruska, Julius. 1926. Tabula Smaragdina: Ein Beitrag zur Geschichte der hermetischen Literatur. Heidelberg: Carl Winter's Universitätsbuchhandlung.

Sahlins, Marshall. 1995. How "Natives" Think, About Captain Cook for Example. Chicago: University of Chicago Press. 
Savage-Smith, Emilie. 1997. "The Depiction of Human Anatomy in the Islamic World." In Francis Maddison, ed., Science, Tools \& Magic, 14-24. London: The Nour Foundation in association with Azimuth Editions and Oxford University Press. Schwab, Julius 1886. Das altindische Tieropfer Mit Benützung handschriftlicher Quellen bearbeitet. Erlangen: Andreas Deichert

Sen, Gananath. 1913-22. Pratyakșaśārīra: Pratyaksha-sháríram. 3 volumes. Calcutta: Gobardhan Press, Standard Drug Press, and Kalpataru Press.

Sen, Gananath. 1966. Siddhāntanidānam. 2 volumes. Varanasi: Caukhamba Sanskrit Series.

Shankar, Darshan and Ram Manohar. 1995. "Ayurvedic Medicine Today: Ayurveda at the Crossroads." In Jan van Alphen and Anthony Aris, eds., Oriental Medicine: An Illustrated Guide to the Asian Arts of Healing, 99-105. London: Serindia.

Sharma, Muralidhar, ed. 1895-99. Śrī-Dhanvantaribhāgavatasamupadișțā, tacchiṣyeṇa suśrutena viracitā suśrutasamhitā ārogyasudhākarasampādakena pharrukhanagaranivāsinā paṃ̣ita muralīdharaśarmaṇā rājavaidyena sānvayasațippaṇikāsapariśiṣtayā bhāṣāțīkayā saṃbhūṣitā. 4 volumes. Bombay: Khemaraja Srikrsnadasa at Srivenkatesvara Press.

Sharma, Muralidhar. [1899]. Mahāmāā kā Vivecana. Bombay: Khemaraja Srikrsnadasa at Srivenkatesvara Press.

Shastri, Parasurama, ed. 1931 [1920]. Dāmodarasūnuśārñgadharācāryaviracitā śārñgadharasaṃhitāa. bhiṣagvarādhamallaviracitadīpikā kāśīrāmavaidyaviracitagūạhārthadīpikābhyāṃ, țīkābhyāṃ, saṃvalitāa. Bombay: Nirnayasagara Press.

Sjoman, Norman E. 1996. The Yoga Tradition of the Mysore Palace. New Delhi: Abhinav Publications.

Staal, Frits. 1993. "Indian Bodies." In Thomas P. Kasulis, Roger T. Ames, and Wimal Dissanayake, eds., Self as Body in Asian Theory and Practice, 59-102. Albany: State University of New York Press.

Storey, C. A. 1958-[1997]. Persian Literature: A Bio-bibliographical Survey. London: Royal Asiatic Society of Great Britain and Ireland.

Sudhoff, Karl. 1907. "Anatomische Zeichnungen (Schemata) aus dem 12. und 13. Jh. und eine Skelettzeichnung des 14. Jhrs." Studien zur Geschichte der Medicin 1: 49-65.

Tawney, C. H., trans. 1924 [1880-84]. The Ocean of Story Being C. H. Tawney's Translation of Somadeva's Kathā Sarit Sāgara (or Ocean of Streams of Story) (ed. N. M. Penzer). 10 volumes. London: Chas J. Sawyer.

Thatte, Dinkar Govind, with Renu and Subhash Chandra Verma. 1988. Acupuncture Marma and Other Asian Therapeutic Techniques. Varanasi: Chaukhambha Orientalia.

Varier, P. S 1925, 1961. Așțāngaśārīram. Kottakal: Arya Vaidya Sala.

Varier, P. S. 1988 [1942, 1969]. Bṛhacchārīram, navīnamatānusāreṇa prācīnaśarīraśāstratattvānām vivaraṇaṃ, teșu sandigdhatayā 'sampūrnatayā vā sthitānām tattvānām ādhunikaśāstrā 'virodhī vistāraś cāsmin suṣthu krtah. Kottakal: P. S Varier's Arya Vaidya Sala. 
Vasudeva, Somadeva. 2004. The Yoga of the Malinivijayottaratantra: Critical Edition, Translation and Notes. Pondicherry: IFP-EFEO.

Watson, Gay. 2002. The Resonance of Emptiness: A Buddhist Inspiration for Contemporary Psychotherapy. London: RoutledgeCurzon.

White, David Gordon. 1996. The Alchemical Body: Siddha Traditions in Medieval India. Chicago: University of Chicago Press.

Wilson, Elizabeth. 1995. "The Female Body as a Source of Horror and Insight in Post-Ashokan Indian Buddhism." In Jane Marie Law, ed. Religious Reflections on the Human Body, 76-99. Indianapolis: Indiana University Press.

Wujastyk, Dominik. 1984a. "An Alchemical Ghost: the Rasaratnakara by Nagarjuna." Ambix 31, 2: 70-83.

Wujastyk, Dominik. 1984b. "The Spikes in the Ears of the Ascetic: An Illustrated Tale in Buddhism and Jainism." Oriental Art 30, 2: 189-94.

Wujastyk, Dominik. 1998. "Science and Vedic Studies." Journal of Indian Philosophy 26, 4: 335-45.

Wujastyk, Dominik. 2002. "Interpréter l'image du corps humain dans l'Inde prémoderne." In Véronique Bouillier and Gilles Tarabout, eds, Les représentations $d u$ corps dans le monde hindou, chapter 2. Paris: CNRS Éditions.

Wujastyk, Dominik. 2003. The Roots of Ayurveda: Selections from Sanskrit Medical Writings. London: Penguin.

Wujastyk, Dominik. 2004. "Review of Gerrit Jan Meulenbeld, A History of Indian Medical Literature." Bulletin of the School of Oriental and African Studies 67, 3: 404-407.

Wujastyk, Dominik. 2007. "A Persian Anatomical Image in a Non-Muslim Manuscript from Gujarat.” Medical History 51, 2: 237-42.

Wujastyk, Dominik. 2008a. "The Evolution of Indian Government Policy on Ayurveda in the Twentieth Century." In Dagmar Wujastyk and Frederick M. Smith, eds., Modern and Global Ayurveda: Pluralism and Paradigms, 43-76. Albany: State University of New York Press.

Wujastyk, Dominik. 2008b. "A Body of Knowledge: The Wellcome Ayurvedic Anatomical Man and His Sanskrit Context." Asian Medicine: Tradition \& Modernity 4: 201-248.

Wujastyk, Dagmar and Frederick M. Smith, eds. 2008. Modern and Global Ayurveda: Pluralism and Paradigms. Albany: State University of New York Press.

Yadav, K. C. 1976. Autobiography of Swami Dayanand Saraswati. New Delhi: Manohar.

Zarrilli, Phillip B. 1998. When the Body Becomes All Eyes: Paradigms, Discourses and Practices of Power in Kalarippayattu, a South Indian Martial Art. New Delhi: Oxford University Press.

Zimmermann, Francis. 1978. "Introducing Western Anatomy to the Practitioners of Classical Indian Medicine: An Ethno-historical Analysis of the Treatises by P. S Varier in the 1920s." In, Asie du Sud, Traditions et Changements, VIth European Conference on Modern South Asian Studies, Sèvres, July 8-13, 1-3. Paris: Centre 
National de la Recherche Scientifique.

Zimmermann, Francis 1983 [1979]. "Remarks on the Conception of the Body in Ayurvedic Medicine." In Beatrix Pfleiderer and Guenther D. Sontheimer, eds, Sources of Illness and Healing in South Asian Regional Literature, 10-26. Heidelberg: South Asia Institute, Department of Tropical Hygiene and Public Health, Department of Indology, Heidelberg University.

Zysk, Kenneth G. 1986. "The Evolution of Anatomical Knowledge in Ancient India with Special Reference to Cross-cultural Influences." Journal of the American Oriental Society 106, 4: 687-705.

Zysk, Kenneth G. 1995. "Vital Breath (Prāṇa) in Ancient Indian Medicine and Religion." In Yosio Kawakita, Shizu Sakai, and Yasuo Otsuka, eds., The Comparison Between Concepts of Life-breath in East and West: Proceedings of the 15th International Symposium on the Comparative History of Medicine-East and West, 33-65. Bretwood: Ishiyaku EuroAmerica.

DOMINIK WUJASTYK is a Research Fellow at the Institute of South Asian, Tibetan and Buddhist Studies, University of Vienna.<ucgadkw@ucl.ac.uk>

Open Access This article is distributed under the terms of the Creative Commons Attribution Noncommercial License which permits any noncommercial use, distribution, and reproduction in any medium, provided the original author(s) and source are credited. 